HRVATSKA AKADEMIJA ZNANOSTI I UMJETNOSTI

RAZRED ZA LIKOVNE UMJETNOST

ARHIV ZA LIKOVNE UMJETNOSTI

ART BULLETIN 67 (2018)

UDK 727:069(497.5)

DOI: https://dx.doi.org/10.21857/ypn4oc8r19

BORKA BOBOVEC

Hrvatski muzej arhitekture

Djela iz fundusa Hrvatskog muzeja arhitekture HAZU predstavljena u MoMA-i

Izložba posvećena jugoslavenskoj arhitekturi Toward a Concrete Utopia: Architecture in Yugoslavia, 1948 - 1980 u Muzeju suvremene umjetnosti (MoMA) u New York-u

U Hrvatskom muzeju arhitekture HAZU pohranjene su ostavštine u kojima su djela iznimne vrijednosti niza vodećih hrvatskih arhitekata, a tijekom ove godine imamo mogućnost prezentacije građe iz našeg fundusa zahtjevnoj internacionalnoj publici. U Muzeju suvremene umjetnosti (MoMA) u New York-u u srpnju je otvorena izložba posvećena jugoslavenskoj arhitekturi Toward a Concrete Utopia: Architecture in Yugoslavia, 1948 - 1980, na kojoj su predstavljeni radovi arhitekata koji su utjecali na formiranje domaće arhitektonske scene. Iz Hrvatskog muzeja arhitekture HAZU izloženo je dvadeset listova projekata i dvije fotografije iz osobnih arhivskih fondova raznih arhitekata čija se ostavština čuva u Muzeju kao i časopis Čovjek i prostor 2/1975 iz biblioteke Muzeja. Također, iz Muzeja je dodatno ustupljen jedan nacrt kao i šest fotografija u digitalnom obliku za potrebe tiskanog kataloga, ukupno trideset eksponata za izložbu i katalog.

Ključne riječi: Hrvatski muzej arhitekture HAZU; arhitekti; ostavštine; Muzej suvremene umjetnosti (MoMA), New York
THE CROATIAN ACADEMY OF SCIENCES AND ARTS

THE DEPARTMENT OF FINE ARTS

THE FINE ARTS ARCHIVES

ART BULLETIN 67 (2018)

ESSAY

UDC 727:069(497.5)

DOI: https://dx.doi.org/10.21857/ypn4oc8r19

\section{BORKA BOBOVEC}

Croatian Museum of Architecture

\section{Works from the HAZU Croatian Museum of Architecture holdings exhibited at MoMA}

An exhibition dedicated to Yugoslav architecture entitled Toward a Concrete Utopia: Architecture in Yugoslavia, $1948-1980$ at the Museum of Modern Art (MoMA) in New York City

The Croatian Academy of Sciences and Arts' Croatian Architecture Museum holds exceptionally valuable works by some of Croatia's leading architects. This year, we are presented with the opportunity to exhibit material from the museum's holdings to the demanding international public. In June of 2018, an exhibition dedicated to Yugoslav architecture entitled Toward a Concrete Utopia: Architecture in Yugoslavia, 1948 - 1980 opened at the Museum of Modern Art in New York City, exhibiting the work of architects who influenced the creation of Croatia's architectural scene. Twenty pages from projects and two photographs from the personal archives of various architects held at the HAZU Croatian Museum of Architecture were exhibited, as was the journal Covjek $i$ prostor, issue 2/1975, from the museum's library. Also, a floor-plan and six digital photographs for a print catalogue were exhibited, making a total of thirty pieces for the exhibition and catalogue.

Key Words: HAZU Croatian Museum of Architecture; architects; heritage; Museum of Modern Art (MoMA), New York 


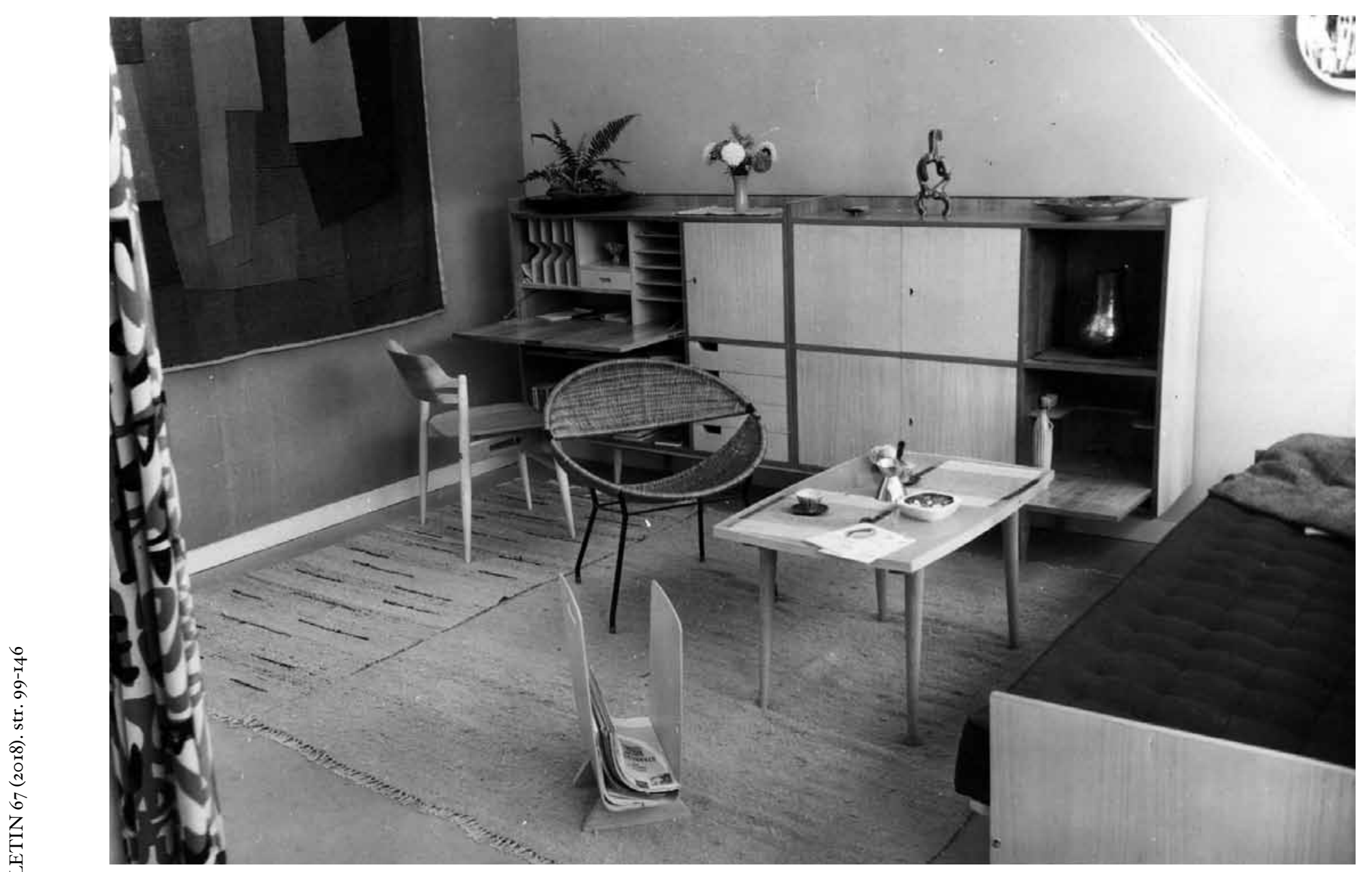

Bernardo Bernardi, Model stana, II. međunarodna revijalna izložba Porodica i domaćinstvo 1958, Zagreb, fotografija, fotograf: nepoznat
Bernardo Bernardi, Model flat, 2nd international Porodica i domaćinstvo 1958 exhibition, Zagreb, photograph. Photographer: unknown 
U Hrvatskom muzeju arhitekture HAZU pohranjene su ostavštine u kojima su djela iznimne vrijednosti niza vodećih hrvatskih arhitekata, a tijekom ove godine imamo mogućnost prezentacije građe iz našeg fundusa zahtjevnoj internacionalnoj publici. Preispitivanje arhitektonskih teorija, ne samo u našim uvjetima, već $i$ šire, u vremenu u kojem političke, ideološke i socijalne komponente imaju sve veću ulogu u razumijevanju i stvaranju nove arhitekture koja se pokazala kao moćan pokretač promjena, rezultat su niza kompleksnih povijesno kulturnih procesa, koji su afirmirane uzore i norme implementirali u postojeći prostor. Zanimanje za arhitekturu nastalu na našim prostorima nedvojbeno raste, a u srpnju otvorena izložba posvećena jugoslavenskoj arhitekturi Toward a Concrete Utopia: Architecture in Yugoslavia, 1948 - 1980 u Muzeju suvremene umjetnosti (MoMA) u New York-u predstavlja radove arhitekata koji su utjecali na formiranje domaće arhitektonske scene. Kako su na samom predstavljanju izložbe 10. srpnja 2018. godine objasnili autori, to su radovi koji „pokazuju potencijal arhitekture u socijalnom angažiranju i transformaciji na načine koji su i danas relevantni“. Autori izložbe su Martino Stierli, kustos za arhitekturu i dizajn u MoMA-i, Vladimir Kulić, profesor na Florida Atlantic University, te suradnica Anna Kats, također iz MoMA-e. U širokoj temi jugoslavenske arhitekture kroz postav se nižu urbane strukture, pojedinačne zgrade, uporaba tehnologije u svakodnevnom životu, spomenička baština i konzumerizam. U četiri grupe nazvane Modernizacija, Globalne mreže, Svakodnevni život i Identiteti izloženo je više od četiri stotine crteža, modela, fotografija i filmova. Kroz odabrane projekte u Modernizaciji prikazana je uloga arhitekture u nagloj urbanizaciji i industrijalizaciji nakon završetka Drugog svjetskog
The Croatian Academy of Sciences and Arts' Croatian Architecture Museum holds exceptionally valuable works by some of Croatia's leading architects. This year, we are presented with the opportunity to exhibit material from the museum's holdings to the demanding international public. In a time in which political, ideological, and social components are playing a greater and greater role in the understanding and creation of architecture as a powerful generator of change, the examination of architectural theory in both Croatia and abroad is the result of a series of complex historical and cultural processes that have implemented affirmed templates and norms in a pre-existing space. Interest in regional architecture is undoubtedly growing. In July of 2018, an exhibition dedicated to Yugoslav architecture entitled Toward a Concrete Utopia: Architecture in Yugoslavia, 1948 - 1980 was opened at the Museum of Modern Art (MoMA) in New York City, presenting the work of architects who influenced the formation of the Croatian architectural scene. As the authors of the exhibition explained at its opening on 10 July 2018, these works "show the potential of architecture in social engagement and transformation in ways that are still relevant today." The authors of the exhibition are Martino Stierli, curator of architecture and design at MoMA, Vladimir Kulić, a professor at Florida Atlantic University, and associate Anna Kats, also from MoMA. Out of the broad subject of Yugoslav architecture, the exhibition deals with low urban structures, individual buildings, the use of technology in everyday life, monuments, and consumerism. More than four hundred drawings, models, photographs, and films were exhibited in four groups entitled Modernisation, Global Networks, Everyday Life, and Identities. The projects selected for Modernisation portray the role of architecture in the rapid urbanisation and 
rata, dok se kroz Globalne mreže čita uloga vanjske politike u stvaranju turističke infrastrukture i izgradnji stambenih naselja i pojedinačnih zgrada. Stambena arhitektura uz jasno čitljivu poruku odvajanja zona za stanovanje, rad i zabavu uz razvoj suvremenog dizajna (sl.1) dio je dionice Svakodnevni život. Ovdje je izložen niz predmeta iz svakodnevne uporabe, od aparata, pa sve do dizajniranog namještaja. Četvrti dio izložbe, pod nazivom Identiteti, analizira odnos različitosti unutar Jugoslavije i težnju za njezinim jedinstvom. ${ }^{1}$

Izložba se ne bavi političkim odnosima, već arhitekturom atribuira pozitivne aspekte i uspješna

$1 \quad$ Stierli, M., Kulić, V., 2018: 7-9 industrialisation after World War II, while Global Networks interprets the role of foreign policy in the creation of tourist infrastructure and the construction of residential areas and individual buildings. Everyday Life portrays residential architecture with the clear message of separate zones for residential space, work, and entertainment alongside the development of modern design (pic. 1). This includes a series of everyday objects from appliances to designer furniture. The fourth part of the exhibition, entitled Identities, analyses the relationships between different groups within Yugoslavia and the aspiration towards unity. ${ }^{1}$

$1 \quad$ Stierli, M., Kulić, V., 2018: 7-9

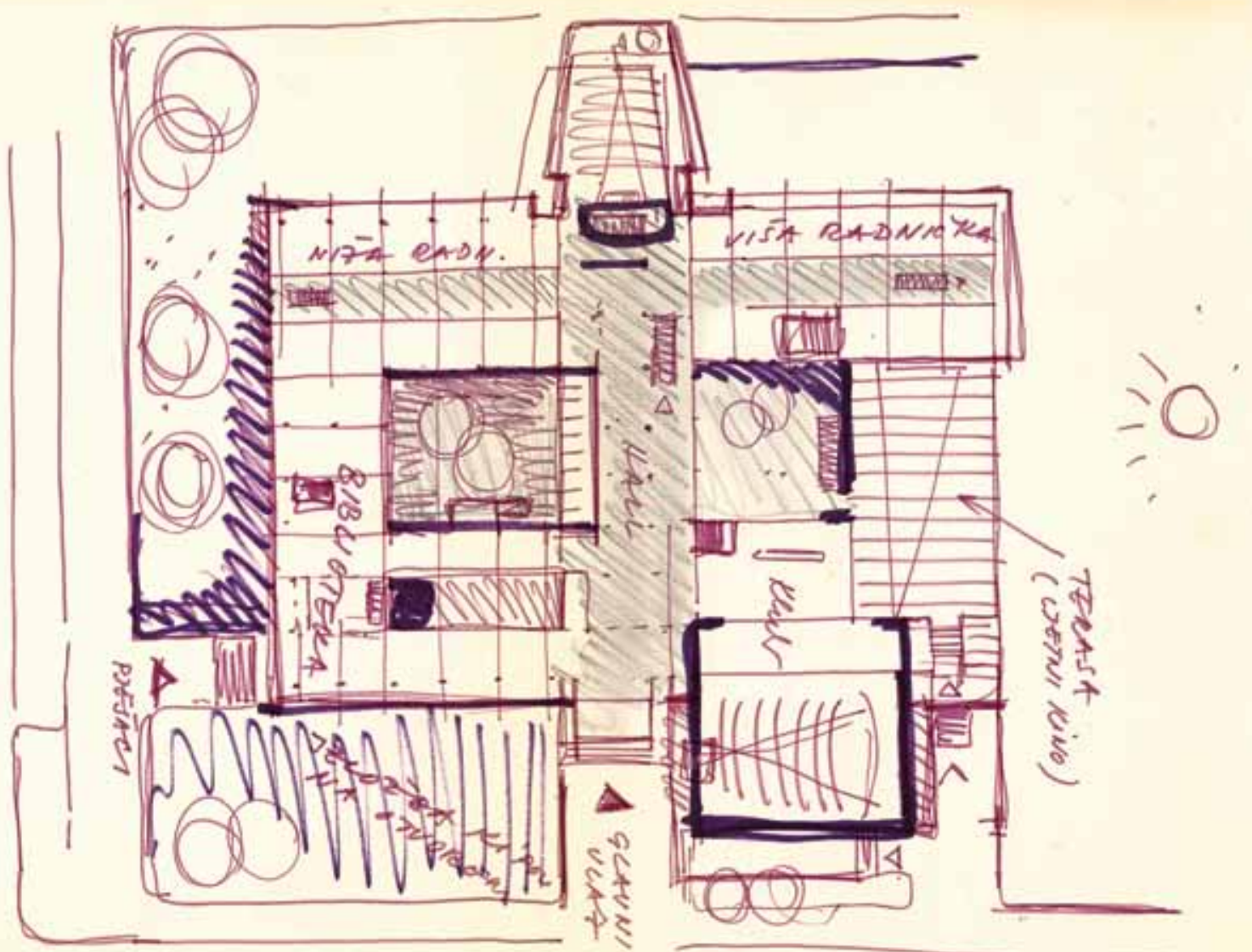

Radovan Nikšić, Radničko sveučilište „Moša Pijade“ (danas Pučko otvoreno učilište, Ulica grada Vukovara 68, Zagreb), 1955-1961., flomaster i olovka na papiru, 29,7 X 41,7 cm
Radovan Nikšić, Moša Pijade Worker's University (today Pučko otvoreno učilište, Ulica grada Vukovara 68, Zagreb), 1955-1961, felt pen and pencil on paper, 29.7 x $41.7 \mathrm{~cm}$ 
dostignuća koja su nastala u vremenu koje je bilježilo promišljanje i analizu postavljenih arhitektonskih istina i odrednica. ${ }^{2} \mathrm{Na}$ ovom mjestu potrebno je naglasiti što je u stvari osnovna kvaliteta te i takve arhitekture koja je $\mathrm{u}$ jednom trenutku napravila znatan otklon $\mathrm{u}$ odnosu na arhitekturu stvaranu u zemljama istočnog bloka. „Hrvatska toga vremena nastoji nastaviti put zacrtan međuratnim razdobljem iako su takva usmjerenja u suprotnosti sa službeno proklamiranim stavovima. Godine 1948. profesor Mohorovičić publicira kritički osvrt na arhitekturu Sovjetskog Saveza u časopisu Republika br. 2/48 pod naslovom 'Ana-

2 Mohorovičić, A., 1975: 7
The exhibition does not deal with political relationships, but rather uses architecture to highlight positive aspects and achievements during a time marked by the contemplation and analysis of pre-established architectural truths and determinants. ${ }^{2}$ Here, we must note the basic qualities of such architecture, which at one point took a great step away from the architecture of the Eastern Bloc countries. "At the time, Croatia strove to remain on the path that had been drawn by the inter-war period, although these trends were at odds with official opinions.In 1948, Professor Mohorovičić published a critical review of Soviet

2 Mohorovičić, A., 1975: 7

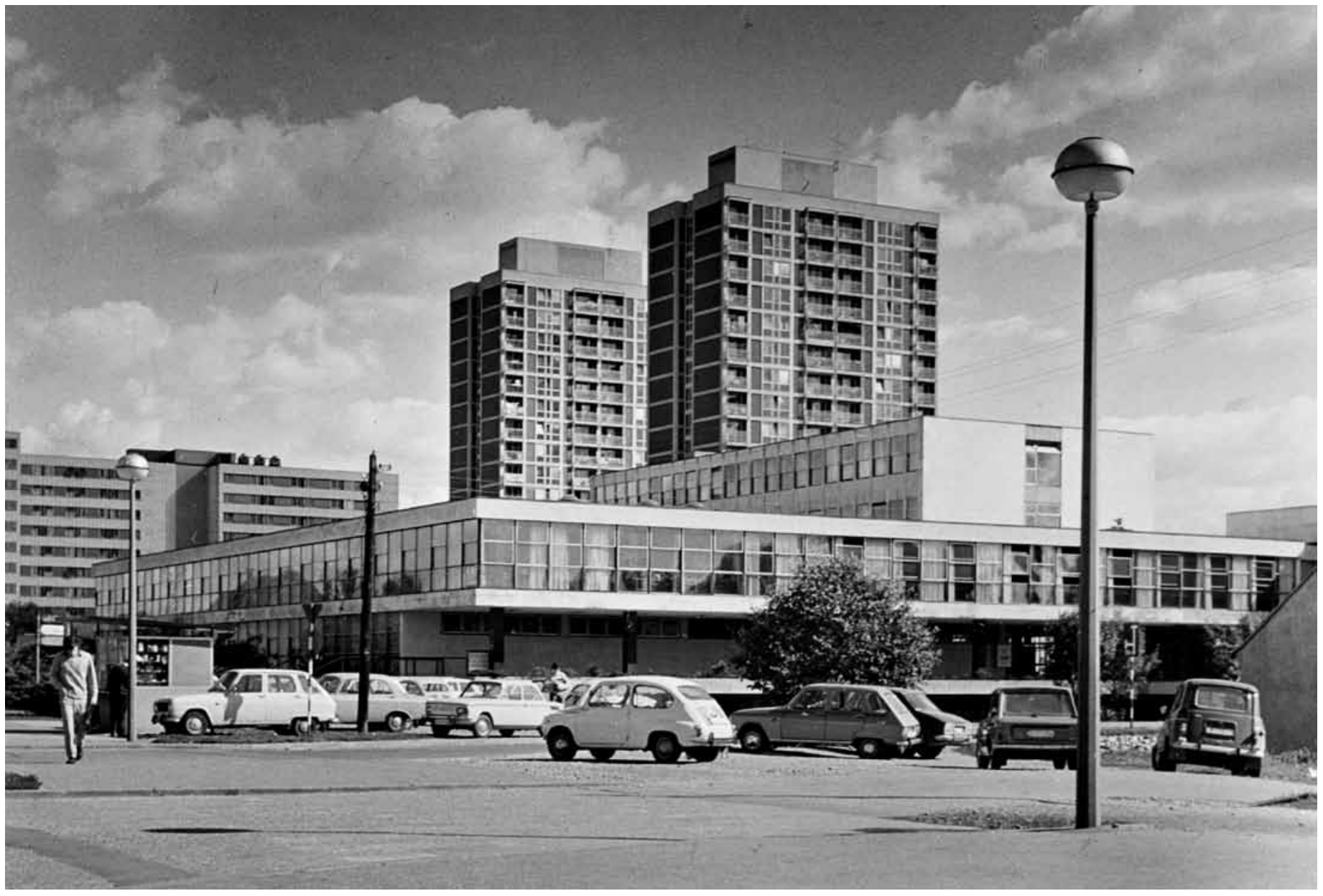

Radovan Nikšić, Radničko sveučilište „Moša Pijade“ (danas Pučko otvoreno učilište, Ulica grada Vukovara 68, Zagreb), 1955-1961., fotografija, fotograf: Krešimir Tadić
Radovan Nikšić, Moša Pijade Worker's University (today Pučko otvoreno učilište, Ulica grada Vukovara 68, Zagreb), 1955-1961, photograph. Photographer: Krešimir Tadić 
liza razvoja arhitektonskog oblikovanja naroda SSSR-a' gdje kaže: Kad pristupamo analizi razvoja arhitektonskog oblikovanja jedne epohe, potrebno je dijalektički raščlaniti zakonitosti i pravilnosti odnosa svih uvjeta objektivne životne stvarnosti prema arhitektonskom oblikovanju. To znači, da valja za pojedinu epohu analizirati osnovne odnose proizvodnje, koji formiraju socijalnu strukturu ljudskog društva, te na temelju toga ustanoviti oblike stvarnog političkog uređenja toga društva, njegove unutarnje međusobne odnose, smjer razvoja njegova misaonog i naučnog kompleksa, te konačno na temelju svega toga fiksirati smjer i oblike njegova umjetničkog izražaja. Međutim, ma koliko se taj proces rasuđivanja čini u principu jednostavan, kod estetske analize nastupa još cijeli niz sekundarnih faktora, koje valja uočiti, a koji su neobično važni za pravilno tumačenje cijelog niza pojava u povijesnom razvoju na polju umjetničkog, a u ovom slučaju arhitektonskog oblikovanja. Ti sekundarni faktori najrazličitijeg značenja, architecture in issue 2/48 of Republika entitled 'An analysis of the development of the architectural design of the nations of the USSR', in which he states: When analysing how the architectural design of a particular epoch developed, one must dialectically analyse regularities in the relationship of all objective living conditions towards architectural design. This means that one should analyse the basic relationships of production for a particular period, which form the social structure of human society, and thus establish the forms of the real political system of this society, its internal relationships, the direction in which its thought and science complex is developing, and, finally, to determine the direction and form of its artistic expression on this basis. However, regardless of how simple this reasoning process seems in principle, aesthetic analysis also involves a host of secondary factors that should be noted - these are unusually important to the correct interpretation of many phenomena in historical development in the field

Boris Magaš, Kombinirana dječja ustanova Mihaljevac (danas Dječji vrtić Vjeverica), 1973-1975., tuš i letraton na pausu, 43, 5 x 106,o cm 
Boris Magaš, Kombinirana dječja ustanova Mihaljevac (danas Dječji vrtić Vjeverica), 1973-1975., tuš i letraton na pausu, 91,0 x 154,5 cm

Boris Magaš, Mihaljevac Combined Children's Institution (today Vjeverica Kindergarten), 1973-1975, ink and letratone on tracing paper, 91.0 x $154.5 \mathrm{~cm}$

djeçja ustanova mihaljevac 
dolnja oteria - vitic

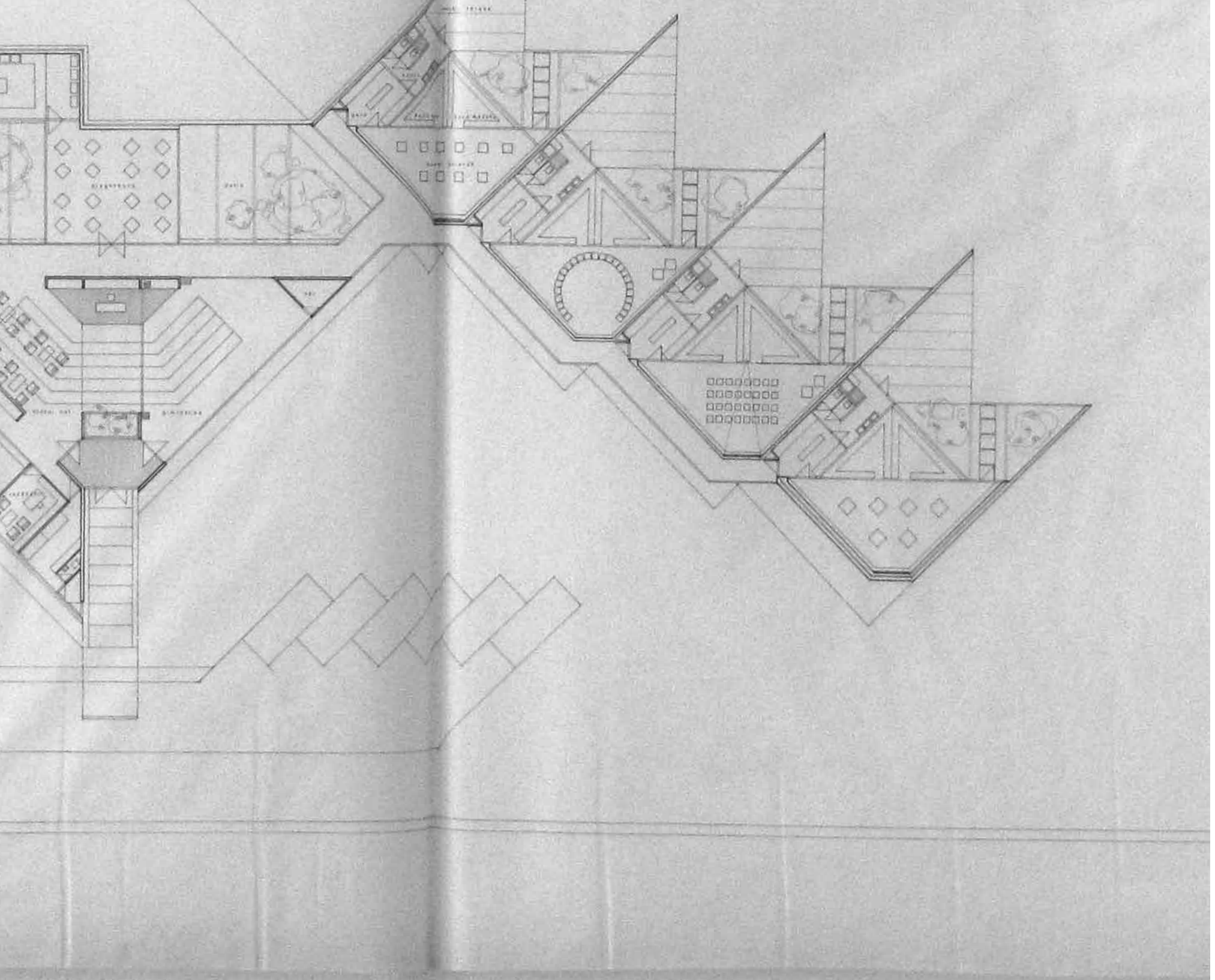




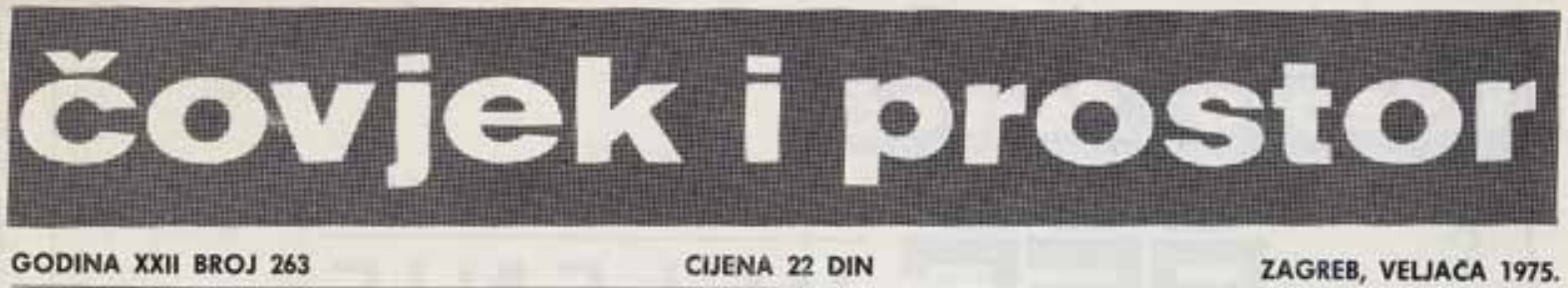

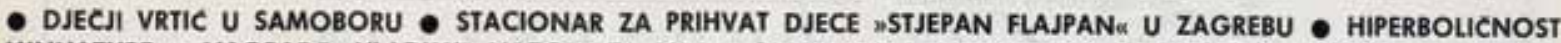
MINIJATURE • NAGRADE ¿VLADIMIR NAZOR॥ ZA $1974 \bullet$ PLANERSKI I INDUSTRISSKI GRADEVINSKI PROCESI U STAMBE. NOJ IZGRADNJI ZA PROMJENJIVE NAMJENE $\bullet$ CRTEZI JOSIPA VANISTE • NA KRAJU POLEMIKE $\bullet$ KOSTA ANGELI RA. DOVANI • VILKO SEFEROV • GRADOVI • VIJESTI I KRONIKA •

DiECAI VRHC U SAMOBORU, AUTOR IVAN CENKOVIC

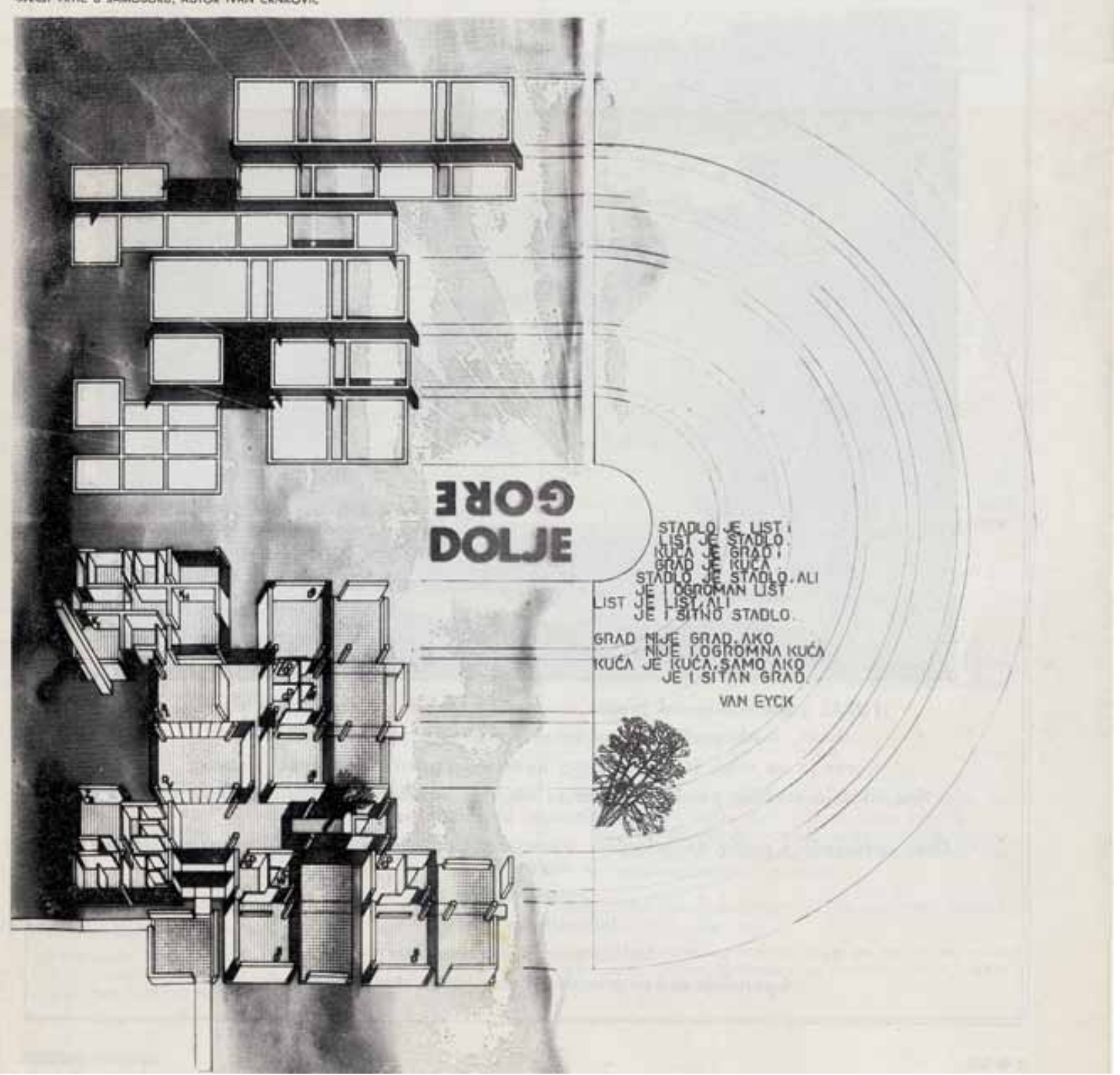


tave bivše države. „Nakon Rezolucije Informbiroa hrvatska je arhitektura bila oslobođena diktirane dogme socijalističkog realizma nastavljajući napore da, u okviru mogućnosti društvene strukture, formira svoje vlastite putove unutar kojih osnova arhitektonske misli ostaje u Mohorovičićevim predavanjima nepromijenjena."5 Arhitektura koja nastaje prihvaćala je stavove suvremenih svjetskih kretanja i nije bila povezana s istovremenom arhitektonskom produkcijom koja nastaje u Sovjetskom Savezu „i u nekim zemljama 'socijalističkog lagera', kojih se arhitektura razvija uz primjenu eklektičkog vokabulara." ${ }^{6}$

Time se naša arhitektura izdvojila od tadašnjeg trenda socijalističkog realizma, a rezultati su prikazani na izložbi u New Yorku na kojoj su teme s područja arhitekture, urbanizma, estetike prostora i kulturne baštine dobile nadgradnju kroz prikaz širokog interesa arhitekata i drugih umjetnika za povezivanje različitih vrsta umjetnosti, kao i početaka uključivanja tehnoloških inovacija u arhitekturu. Stvoren je uvid u domaću arhitektonsku scenu kroz prezentiranje vodećih arhitekata i umjetnika koji su djelovali u bivšoj državi, njihovih razmišljanja, želja, znanja i mogućnosti. Prepoznajući utjecaj koji ovakva događanja imaju

5 Ibid, 288

6 Ibid, 288 which spoke out against and criticised Soviet architecture, unquestionably affected the formation of a different approach that was to mark architecture that developed across the entire former state in coming years. "After the Informbiro Resolution, Croatian architecture was freed from the dictated dogma of socialist realism, and efforts continued to form separate paths allowed by the social structure, within which the foundation of architectural thought remained unchanged in Mohorovičić's lectures." 5 The architecture that resulted accepted the opinions of modern international trends and was unconnected to contemporaneous architectural production in the Soviet Union "and in some countries of the 'socialist camp', whose architecture developed with the application of an eclectic vocabulary." 6

This is what differentiated Croatian architecture from the trend of socialist realism at the time. The results of this were displayed at the exhibition in New York, where topics from the fields of architecture, urban design, spatial aesthetics, and cultural heritage were bolstered by the portrayal of the broad interest of architects and other artists in connecting different kinds of art, as well as of the beginnings of the use of technological inno-

5 Ibid, 288

6 Ibid, 288 


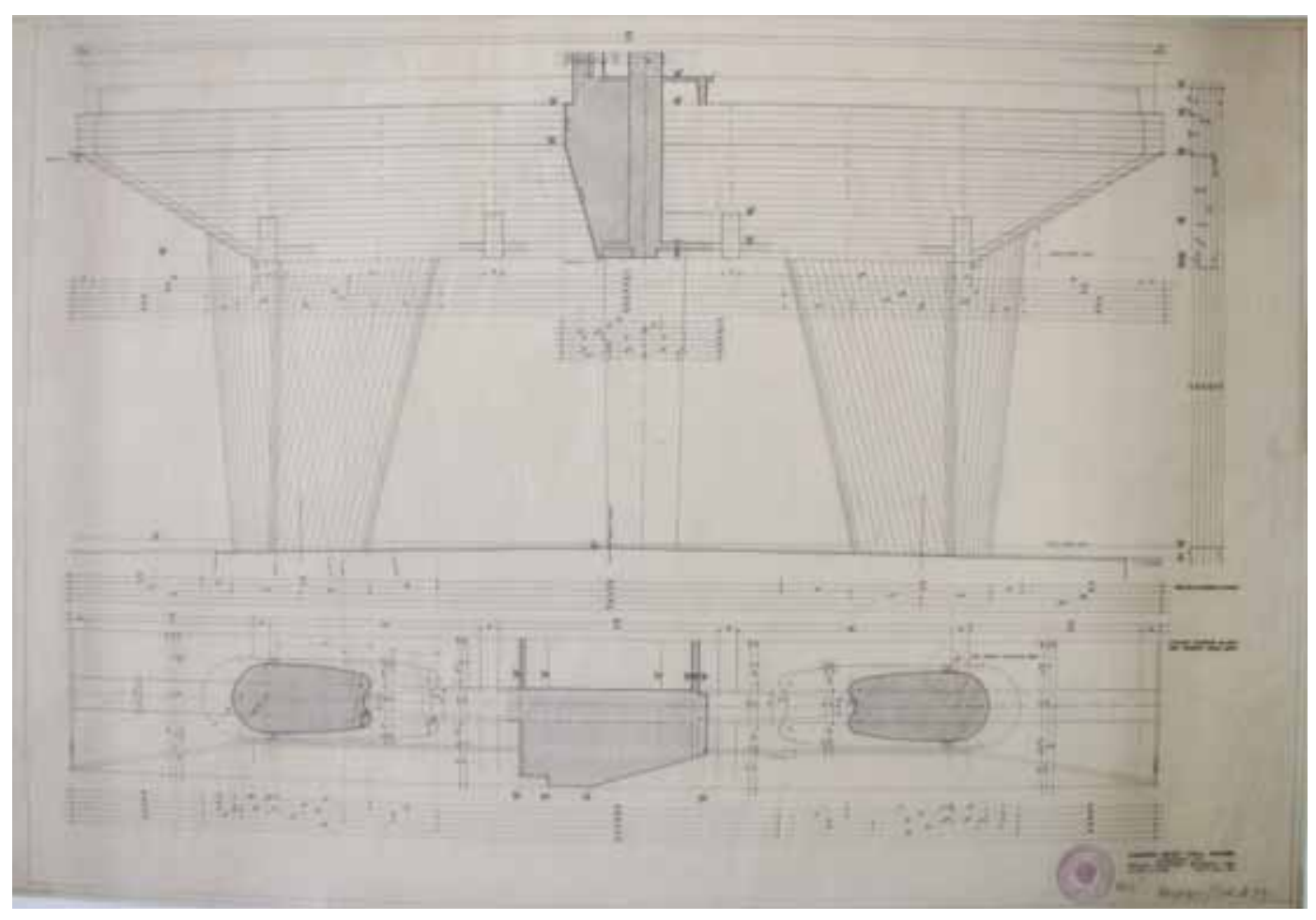

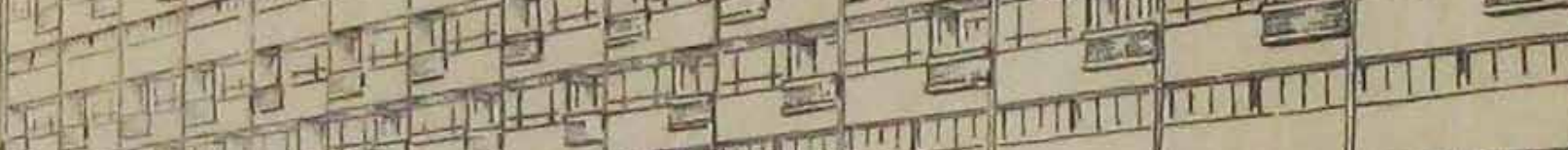

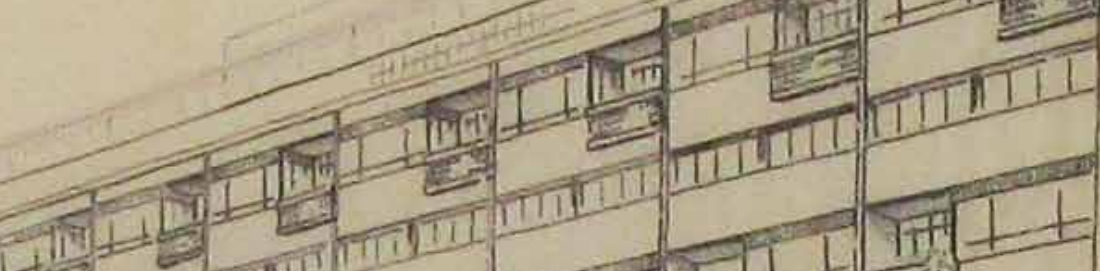
1.-14.

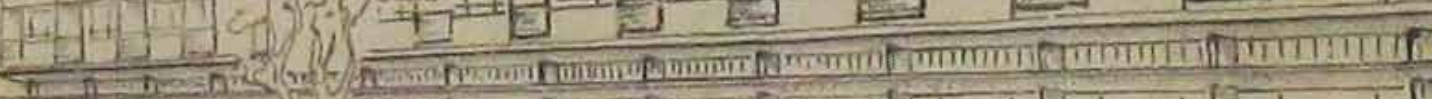

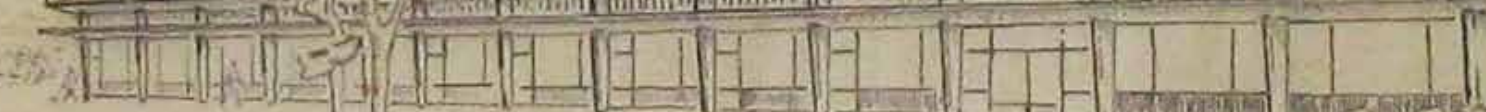

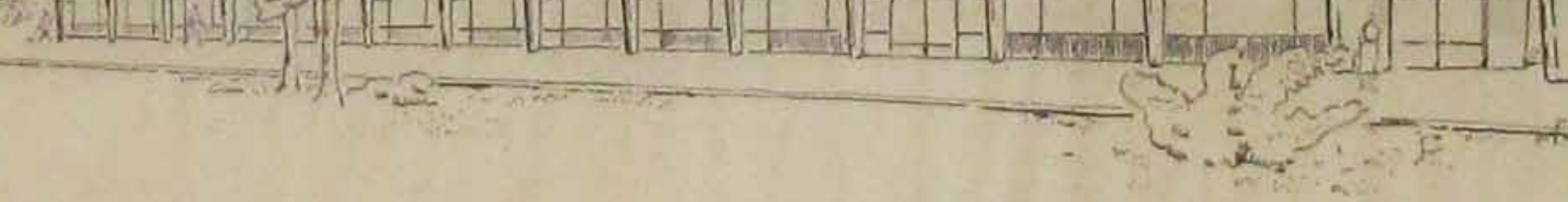


Drago Galić, Stambena zgrada vojne oblasti Zagreb (danas Ulica grada

Vukovara 35-35a i 43-43a, Zagreb), 1954., tuš na pausu, „Stambeni objekt NOG-a Zagreba, Miramarska (...) nacrt broj 7011", $56,6 \times 84,0 \mathrm{~cm}$

Drago Galić, Zagreb military area block of flats (today Ulica grada Vukovara 3535a and 43-43a, Zagreb), 1954, ink on tracing paper, "Stambeni objekt NOG-a Zagreba, Miramarska (...) nacrt broj 7011”, $56.6 \times 84.0 \mathrm{~cm}$

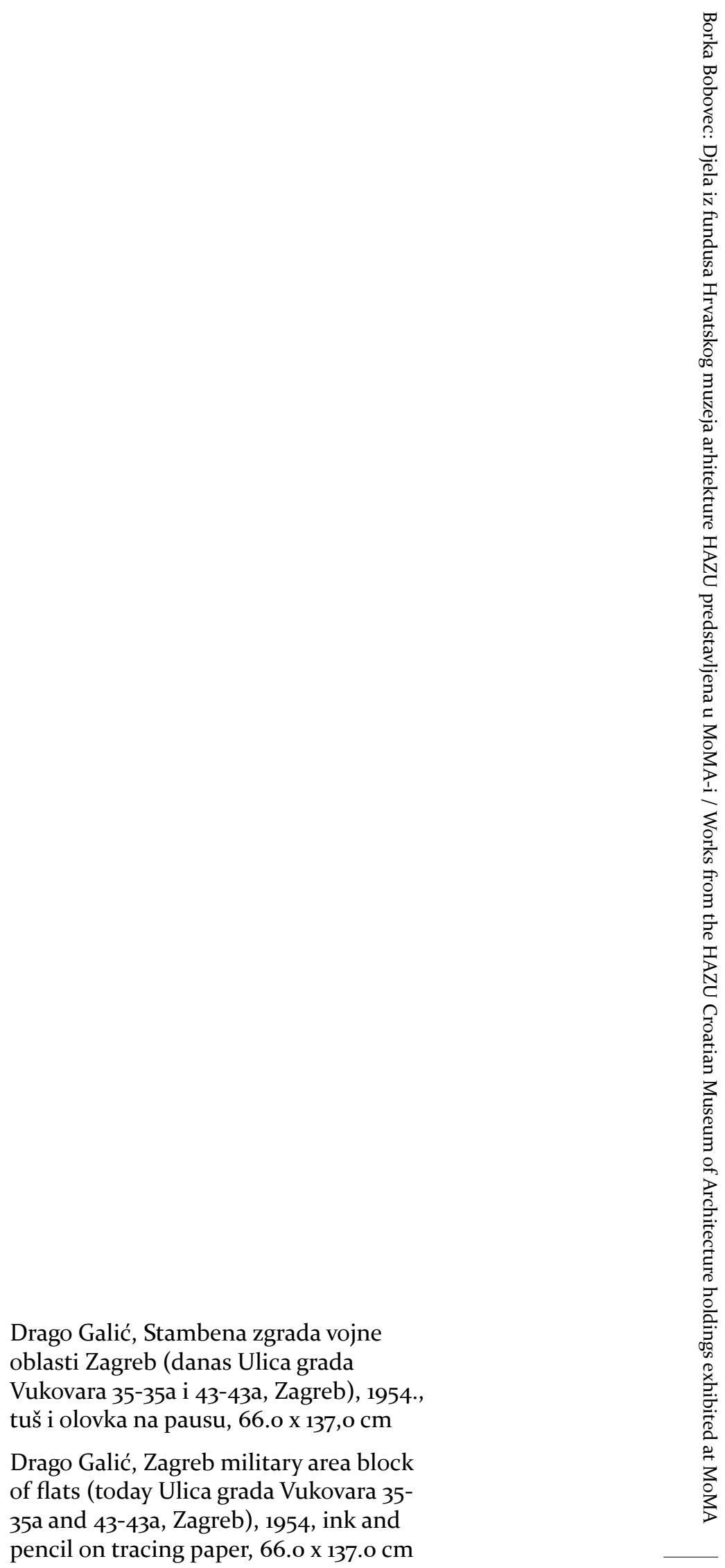




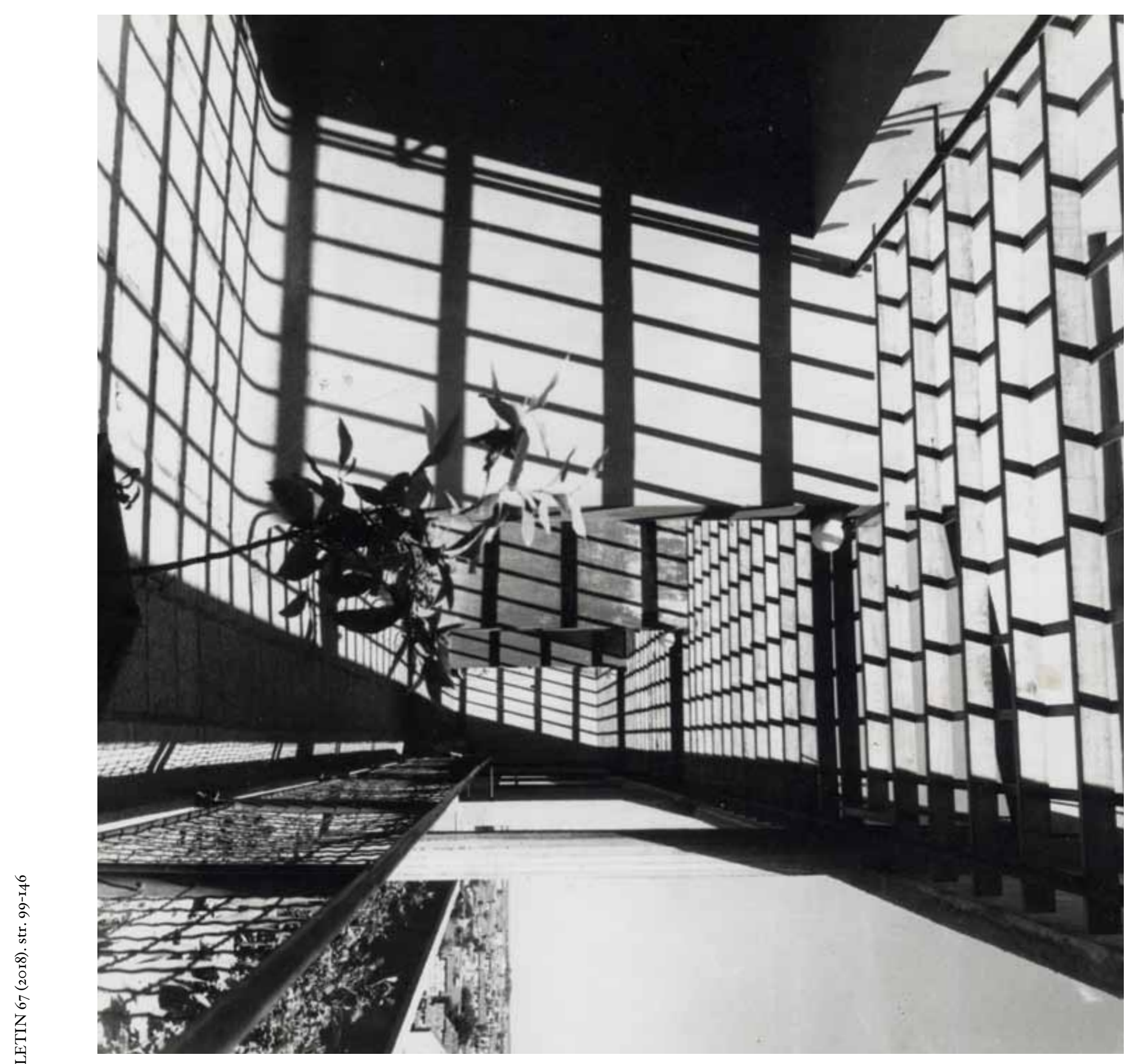

Drago Galić, Stambena zgrada vojne oblasti Zagreb (danas

Ulica grada Vukovara 35-35a i 43-43a, Zagreb), 1954., fotografija, fotograf: Ante Roca
Drago Galić, Zagreb military area block of flats (today Ulica grada Vukovara 35-35a and 43-43a, Zagreb), 1954, photograph. Photographer: Ante Roca 


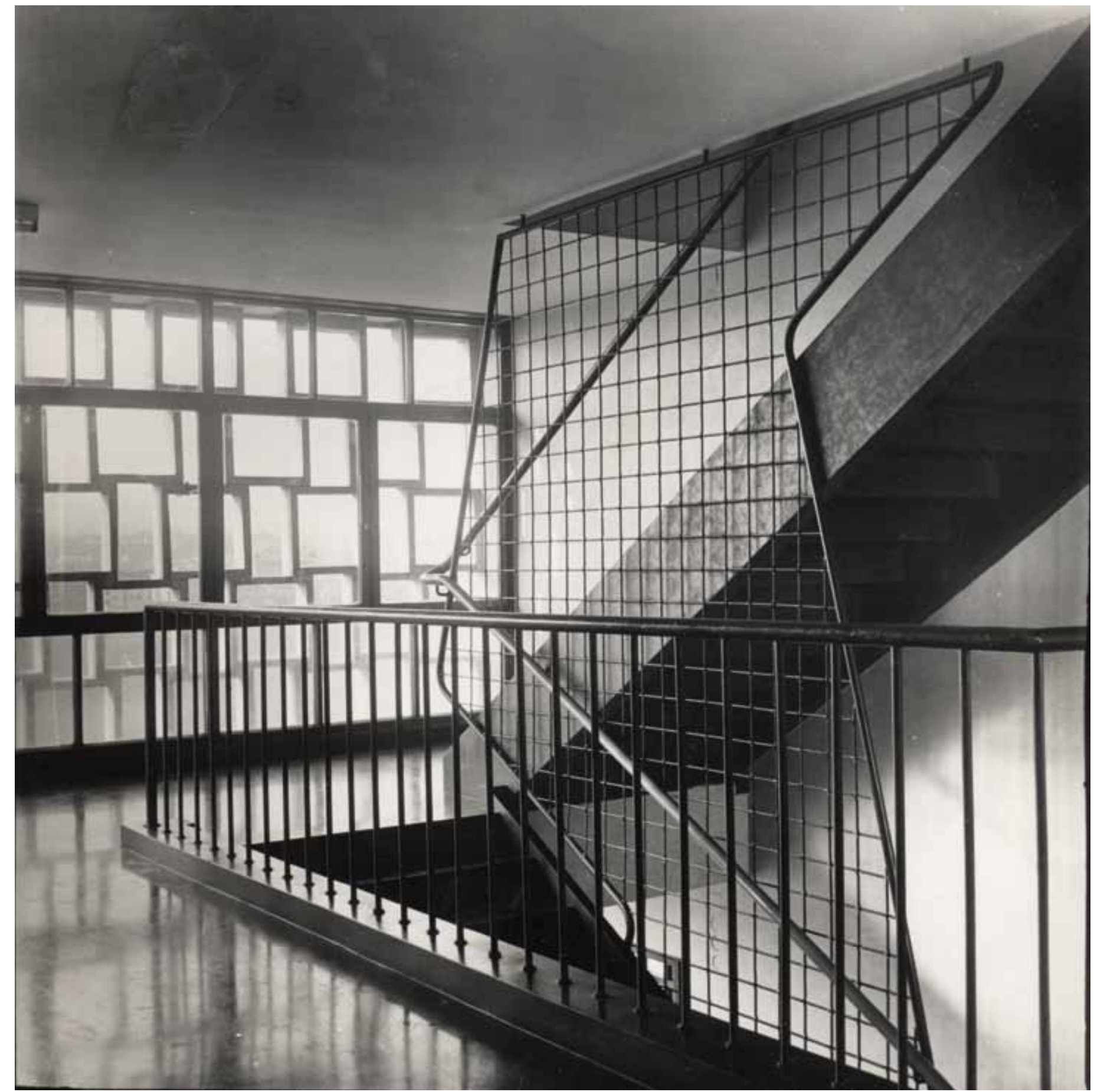

Drago Galić, Stambena zgrada vojne oblasti Zagreb (danas Ulica grada Vukovara 35-35a i 43-43a, Zagreb), 1954., fotografija, fotograf: Ante Roca
Drago Galić, Zagreb military area block of flats (today Ulica grada Vukovara 35-35a and 43-43a, Zagreb), 1954, photograph. Photographer: Ante Roca 
Drago Galić, Stambena zgrada vojne oblasti Zagreb (danas Ulica grada Vukovara 35-35a i 43-43a, Zagreb), 1954., fotografija, fotograf: Ante Roca

Drago Galić, Zagreb military area block of flats (today Ulica grada Vukovara 35-35a and 43-43a, Zagreb), 1954, photograph. Photographer: Ante Roca

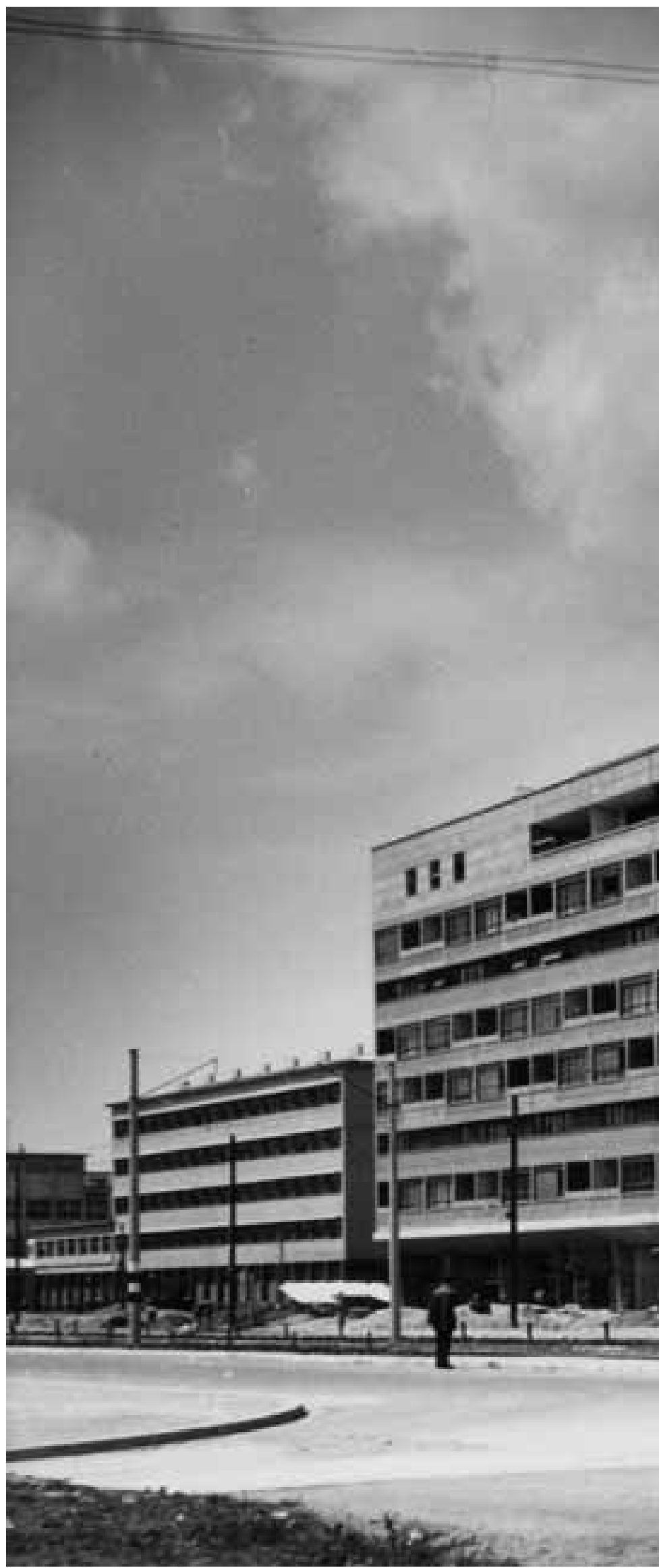




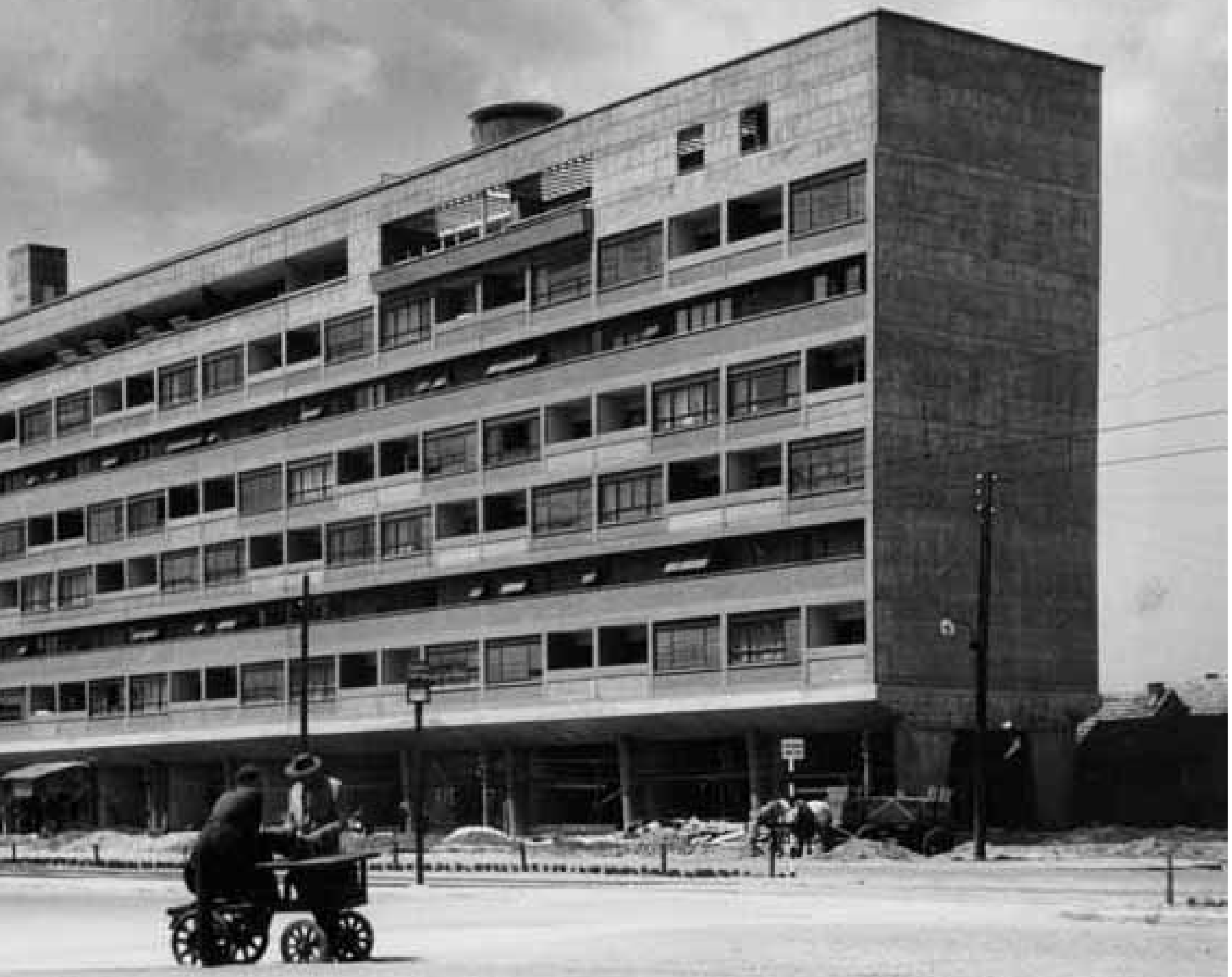


Ivan Vitić, Regulacija bloka u Laginjinoj ulici (danas Laginjina 7-7a-9 /

Vojnovićeva, Zagreb), 1958-1962., tempera, olovka i tuš na papiru, „Vitić Zgb. 25.X.6o.“, $70,2 \times 100,00 \mathrm{~cm}$

Ivan Vitić, Urban design of a block of flats in Laginjina street (today Laginjina 7-7a-9 / Vojnovićeva, Zagreb), 1958-1962, tempera, pencil and ink on paper, "Vitić Zgb. 25.X.6o.", 70.2 x $100.00 \mathrm{~cm}$

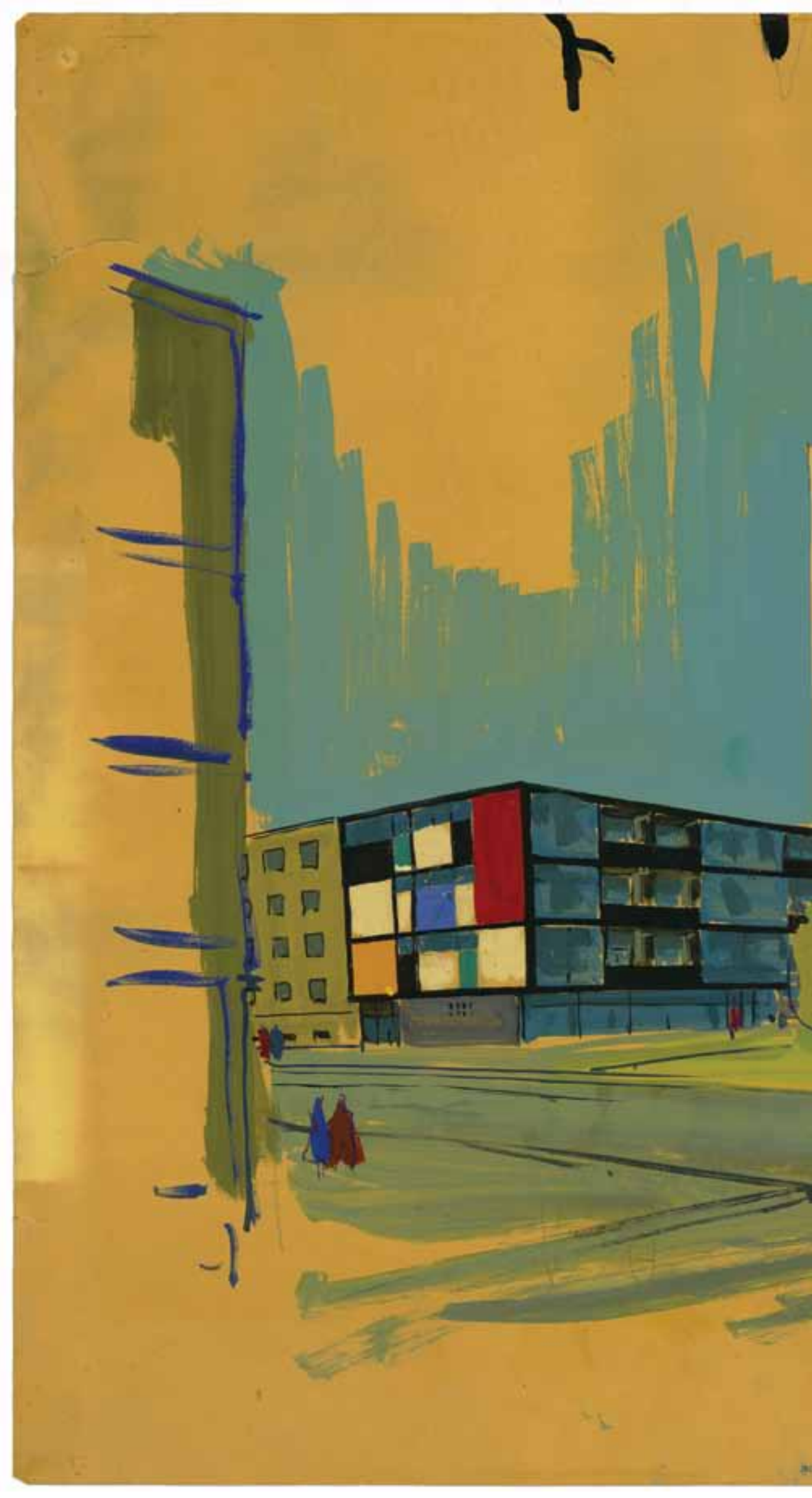




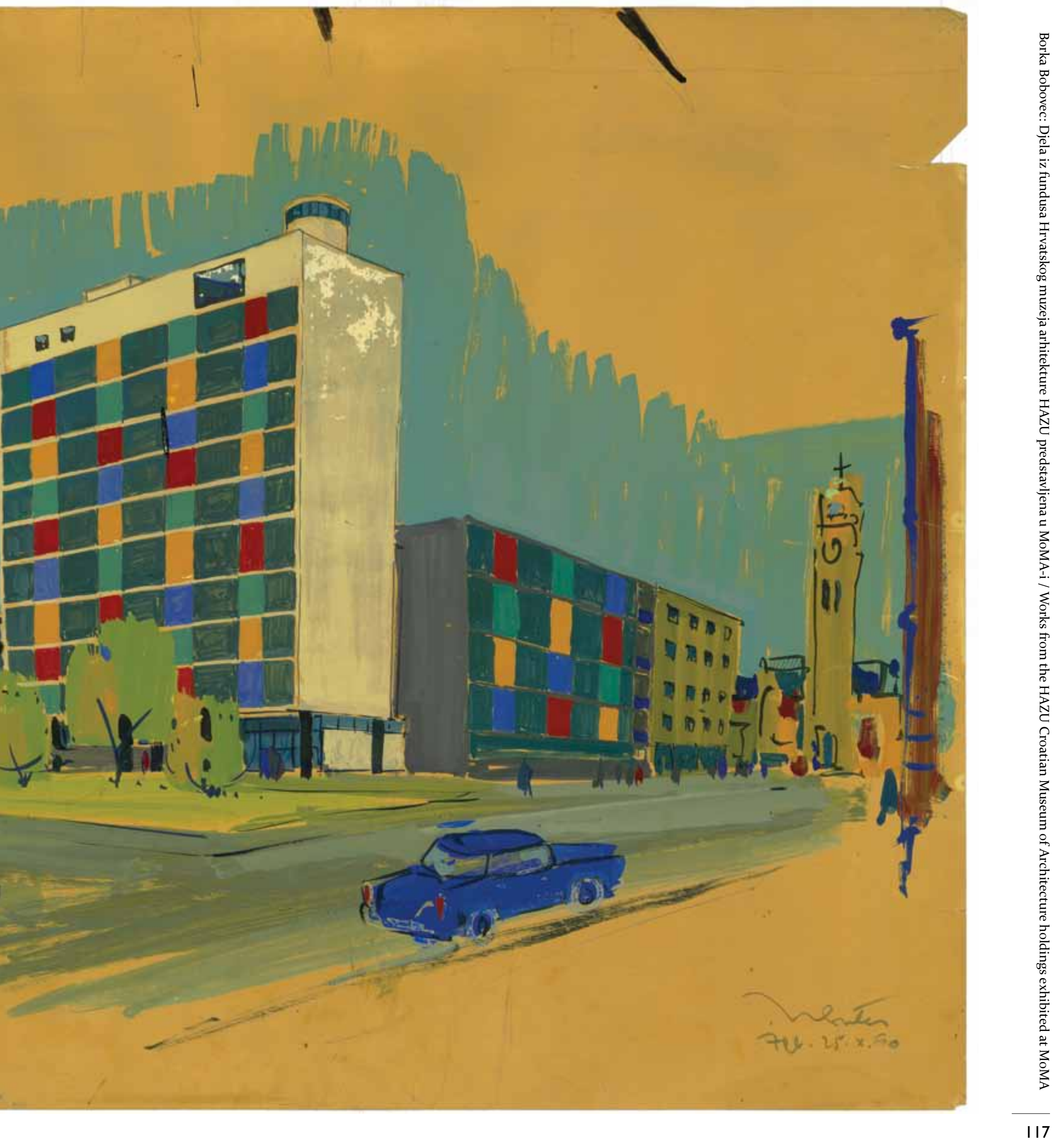




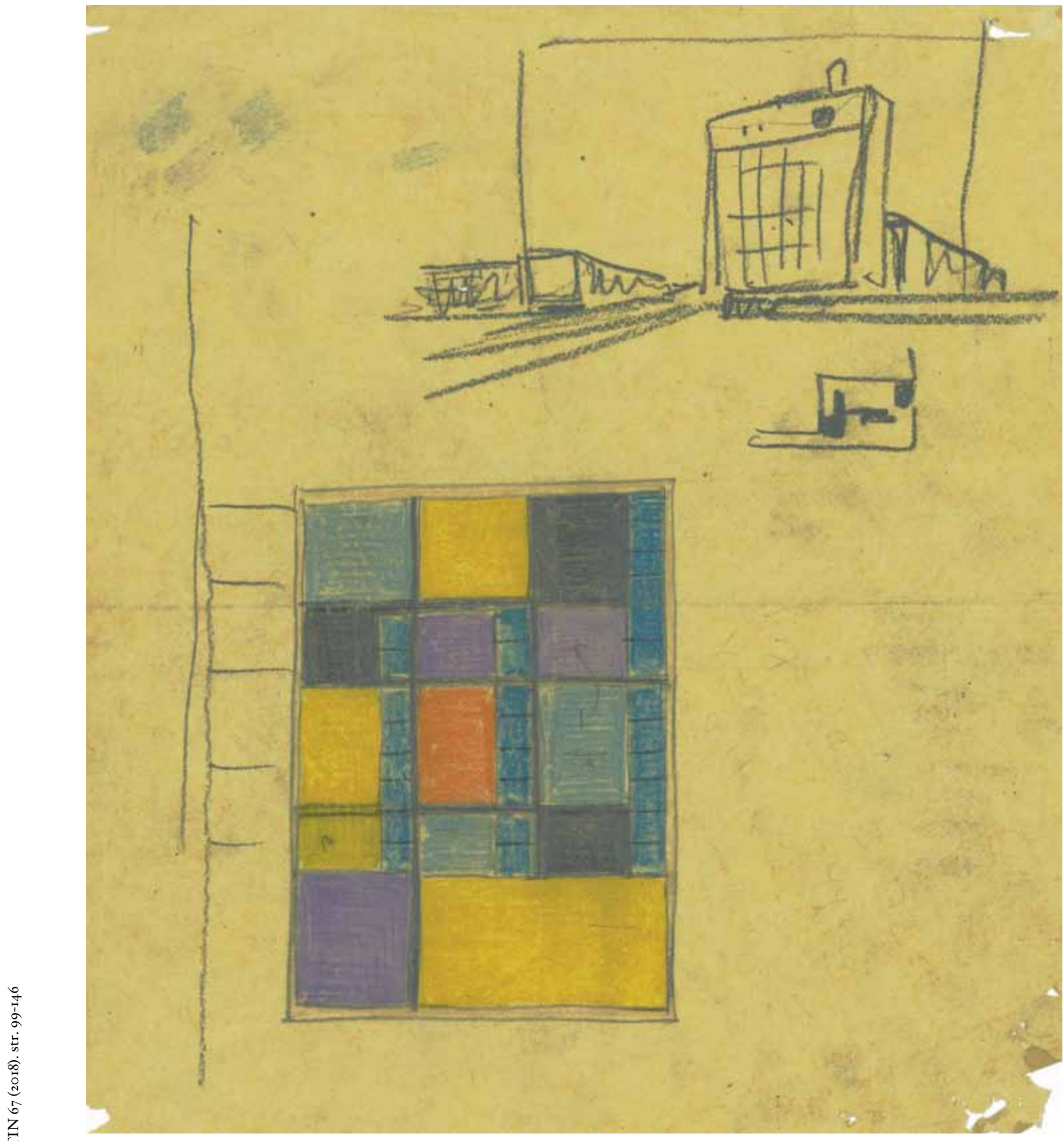

Ivan Vitić, Regulacija bloka u Laginjinoj ulici (danas Laginjina 7-7a-9 / Vojnovićeva, Zagreb), 1958-1962., olovka, olovka u boji i pastel na papiru za skiciranje, $35,0 \times 32,0 \mathrm{~cm}$
Ivan Vitić, Urban design of a block of flats in Laginjina street (today Laginjina 7-7a-9 / Vojnovićeva, Zagreb), 19581962, pencil, coloured pencil, and pastel on sketch paper, $35.0 \times 32.0 \mathrm{~cm}$ 
ne samo među arhitektima već i među svima koji su u doticaju s arhitekturom i kulturom, moguće je aktiviranje šire valorizacije i prepoznavanja mjesta arhitekture u društvu, kroz odabir recentnih arhitektonskih djela, njihovih protagonista i utjecajem koji su imali na oblikovanje prostora. A $\mathrm{u}$ tome razdoblju arhitekti se pojavljuju u najrazličitijim ulogama kojima daju aktivan doprinos obnovi i izgradnji svih struktura, od graditeljskih do socijalnih i društvenih.

Vrijeme je to u kome su izvedene mnoge sjajne zgrade koje su obilježile razdoblje, a trenutna izložba u MoMA-i za koju su eksponati prikupljeni iz mnogih muzeja i arhiva, kao i od živućih arhitekata i njihovih nasljednika, predstavlja izbor koji je moguće promatrati u širem kontekstu. Iz Hrvatskog muzeja arhitekture HAZU izloženo je dvadeset listova projekata i dvije fotografije iz osobnih arhivskih fondova raznih arhitekata čija se ostavština čuva u Muzeju kao i časopis Čovjek i prostor 2/1975 iz biblioteke Hrvatskog muzeja arhitekture HAZU. Također, iz Muzeja je dodatno ustupljen jedan nacrt kao i šest fotografija $u$ digitalnom obliku za potrebe tiskanog kataloga, ${ }^{7}$ ukupno trideset eksponata za izložbu i katalog. Značajan dio eksponata stigao je i iz Zbirke Richter Muzeja suvremene umjetnosti. A jedan od izloženih projekata koji je odredio kriterije i smjer kojim je išla arhitektura toga vremena je Radničko sveučilište „Moša Pijade“ (sl.2 i 3), djelo Radovana Nikšića i Ninoslava Kučana „kojim je postavljen novi kanon u zagrebačkoj arhitekturi, referentno djelo koje sažima domaću tradiciju međuratne moderne i najviše standarde aktualne europske urbatekture ". ${ }^{8}$ Reperi su bili postavljeni i od arhitekture se očekivalo puno.

No krenimo redom, izložba je pripremana tri godine i izbor sigurno nije bilo jednostavno načiniti. Osim glavnih kustosa na terenu je radio niz priznatih domaćih stručnjaka koji su istraživali, predlagali i pisali. Izbor koji je predstavio hrvat-

7 Katalog izložbe, 2018: 30, 40, 78, 92 i 174

8 Tonković, Z., 2005: 41 vations in architecture. This provided insight into the local architectural scene through the presentation of leading architects and artists who worked in the former Yugoslavia - their thoughts, desires, knowledge, and abilities. By recognising the influence such events have not only on architects, but on all who come into contact with architecture and culture, it becomes possible to more broadly evaluate and recognise architecture's place in society through a selection of recent architectural creations, their protagonists, and the influence they have had on urban design. During this period, architects appeared in various roles, thus providing active contributions to the construction of architectural and social structures alike.

During this period, many brilliant buildings that marked the era were created; the current exhibition at MoMA, for which exhibits were collected from many museums, archives, living architects and their successors, represents a selection that can be viewed in a broader context. Twenty pages from projects and two photographs from the personal archives of various architects held at the HAZU Croatian Museum of Architecture were exhibited, as was the journal Čovjek $i$ prostor, issue 2/1975 from the museum's library. Also, a floor-plan and six digital photographs were provided for the print catalogue, ${ }^{7}$ making a total of thirty pieces for the exhibition and catalogue. A significant part of the exhibit also came from the Richter Collection of Zagreb's Museum of Contemporary Art. One of the projects exhibited, which defined the criteria and direction of the architecture of the time, was the Moša Pijade Workers' University (pic. 2 and 3), the work of Radovan Nikšić and Ninoslav Kučan; "it established a new canon in Zagreb's architecture, a referential work that summarised the local inter-war modern tradition and the highest standards of current European urbatecture". ${ }^{8}$ The benchmark had been set, and much was expected of architecture.

\footnotetext{
7 Exhibition catalogue, 2018: 30, 40, 78, 92 i 174

8 Tonković, Z., 2005: 41
} 
Ivan Vitić, Motel Sljeme, nerealizirani projekt, 1964., tuš na pausu, 98,5 X 65,5 cm Ivan Vitić, Motel Sljeme, draft project, 1964 , ink on tracing paper, $98.5 \times 65.5 \mathrm{~cm}$ 

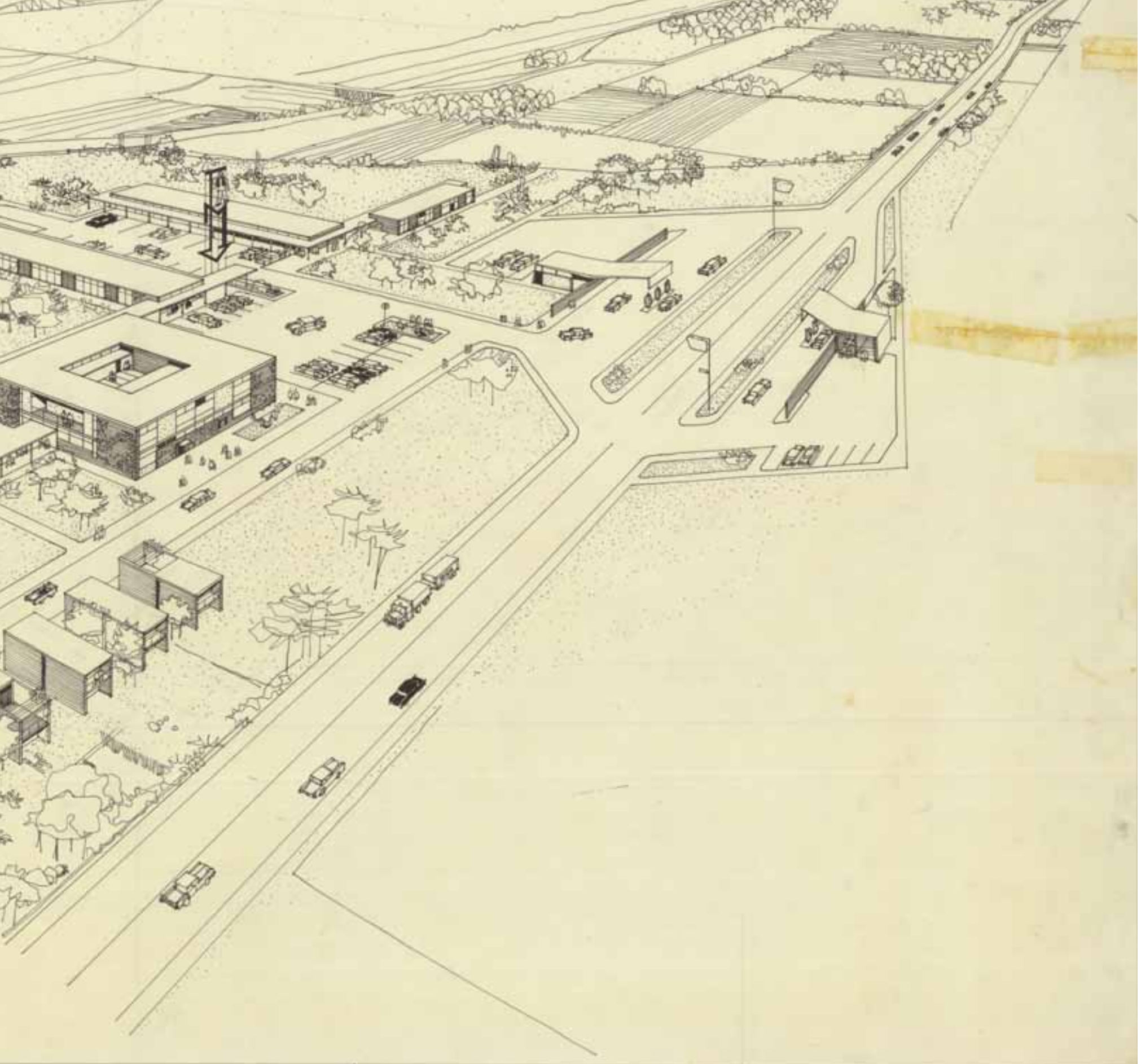

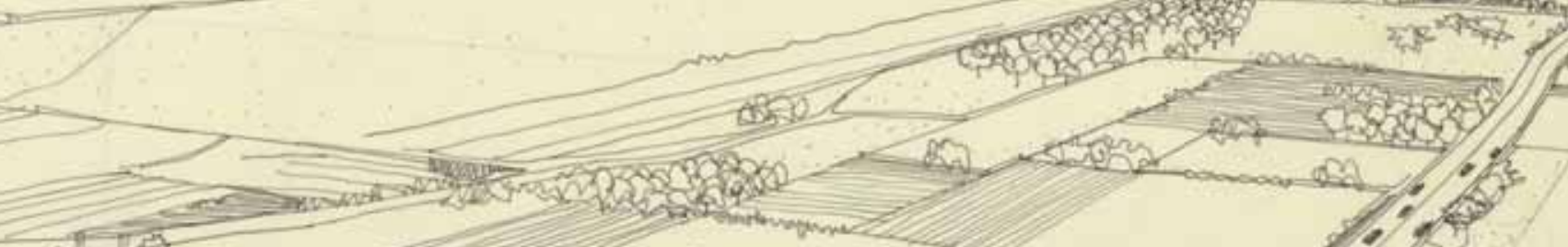

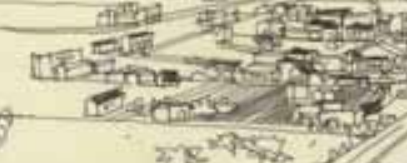


sku arhitekturu prikazuje projekte koji pršte energijom, i čija prezentacija ima snagu i domete koji su i danas relevantni u recentnim teoretskim razmatranjima. Izložena je arhitektura različitih formata, od dječjeg vrtića Borisa Magaša na Mihaljevcu (sl.4 i 5) koji leži položen uz brijeg iz kojeg izlazi neobična kombinacija trokutastih prizmi, i vrtića Ivana Crnkovića u Samoboru (sl.6), koji je projektiran u maniri malog grada, sa ulicama i trgovima, mjestima susreta, rada, odmora i zabave, bez suvišnih pregrada i prepreka, do stambenih blokova Drage Galića u Ulici grada Vukovara (sl.7, 8, 9, 10 i 11) koji kombiniraju stanovanje i ateliere na zadnjem katu s poslovnim prostorima i trgovinama u prizemlju. Tu je svoje mjesto našao stambeni blok Narodne banke u Zagrebu Ivana Vitića (sl.12 i 13) te njegov Njemački paviljon na Zagrebačkom velesajmu i nerealizirani projekt Motela Sljeme (sl.14). Zagrebački velesajam predstavljen je i kroz paviljon Mašinogradnje Božidara Rašice (sl.15) Kroz postav se nižu stambeni blok Nevena Šegvića u Zadru (sl.16), kao i njegov hotel Excelsior u Dubrovniku. Tu je Boris Magaš i njegovi hoteli Haludovo i Solaris, Ante Čičin-Šain i Žarko Vincek predstavljeni su također hotelima Libertas (sl.17) i Palace u Dubrovniku, kao i Zdravko Bregovac s Ambasadorom u Opatiji.

Nadalje, prisutna je i sportska arhitektura, Vladimir Turina predstavljen je a projektom višenamjenskog bazena u Rijeci (sl.18, 19, 20, 21 i 22), i ponovno Boris Magaš s projektom Gradskog stadiona Poljud u Splitu (sl.23, 24 i 25). Osim radova koji su izvedeni u Hrvatskoj, tu je i značajan broj projekata naših arhitekata koji su izvedeni u drugim republikama bivše države, od katoličke crkve svetog Antuna u Podgorici Borisa Krstulovića i Zvonimira Vrkljana (sl.26 i 27), do Magaševog Muzeja narodne revolucije u Sarajevu (sl.28 i 29). Značajno mjesto na izložbi zauzima Nacionalna biblioteka u Prištini Andrije Mutnjakovića (sl.31 i 32), interpretacija regionalne arhitekture suvremenim arhitektonskim izrazom.

U nizu arhitekata značajno mjesto zauzima Juraj Neidhardt, čovjek koji je oblikovao arhitekton-
However, let us begin from the beginning preparations for the exhibition lasted three years, and the choice was certainly difficult. Aside from the head curators, many renowned experts from the region were involved in research, design, and writing for the exhibition. The selection representing Croatian architecture consists of projects that radiate energy and whose presentation has a strength and range that is still relevant in recent theoretical considerations. Architecture of various formats is exhibited: Boris Magašs kindergarten in Zagreb's neighbourhood of Mihaljevac (pic. 4 and 5), which lies prone on a hill, featuring an unusual combination of triangular prisms; Ivan Crnković's kindergarten in Samobor (pic. 6), which was designed like a small town with streets, squares, and places to meet, work, rest, and play without excessive fences or obstacles; Drago Galićs blocks of flats in Zagreb's Vukovar Street (pic. 7, 8, 9, 10, and 11), which feature flats and ateliers on the top floor and business spaces and shops in the ground floor. Ivan Vitić's Narodna banka block of flats (pic. 12 and 13) his German Pavilion at Zagreb Fair, and his Motel Sljeme draft project (pic. 14) also found their place here. Zagreb Fair was also presented through the Mašinogradnja Pavilion by Božidar Rašica (pic. 15). Neven Šegvić's block of flats in Zadar (pic. 16) and his Excelsior Hotel in Dubrovnik also appear throughout the exhibition. Boris Magaš’s Haludovo and Solaris hotels, Ante Čičin-Šain and Žarko Vincek's Libertas (pic. 17) and Palace hotels in Dubrovnik, and Zdravko Bregovac's Ambasador Hotel in Opatija also appear.

Sports architecture is also present through Vladimir Turin's multivalent swimming pool in Rijeka (pic. 18, 19, 20, 21, and 22) and Boris Magaš's Poljud City Stadium project in Split (pic. 23, 24, and 25). Aside from works constructed in Croatia, there are also a significant number of projects by Croatian architects built in other republics of the former state, from Boris Krsulović and Zvonimir Vrkljan's Catholic Church of St. Anthony in Podgorica, Montenegro (pic. 26 and 27) to Magaš’s 


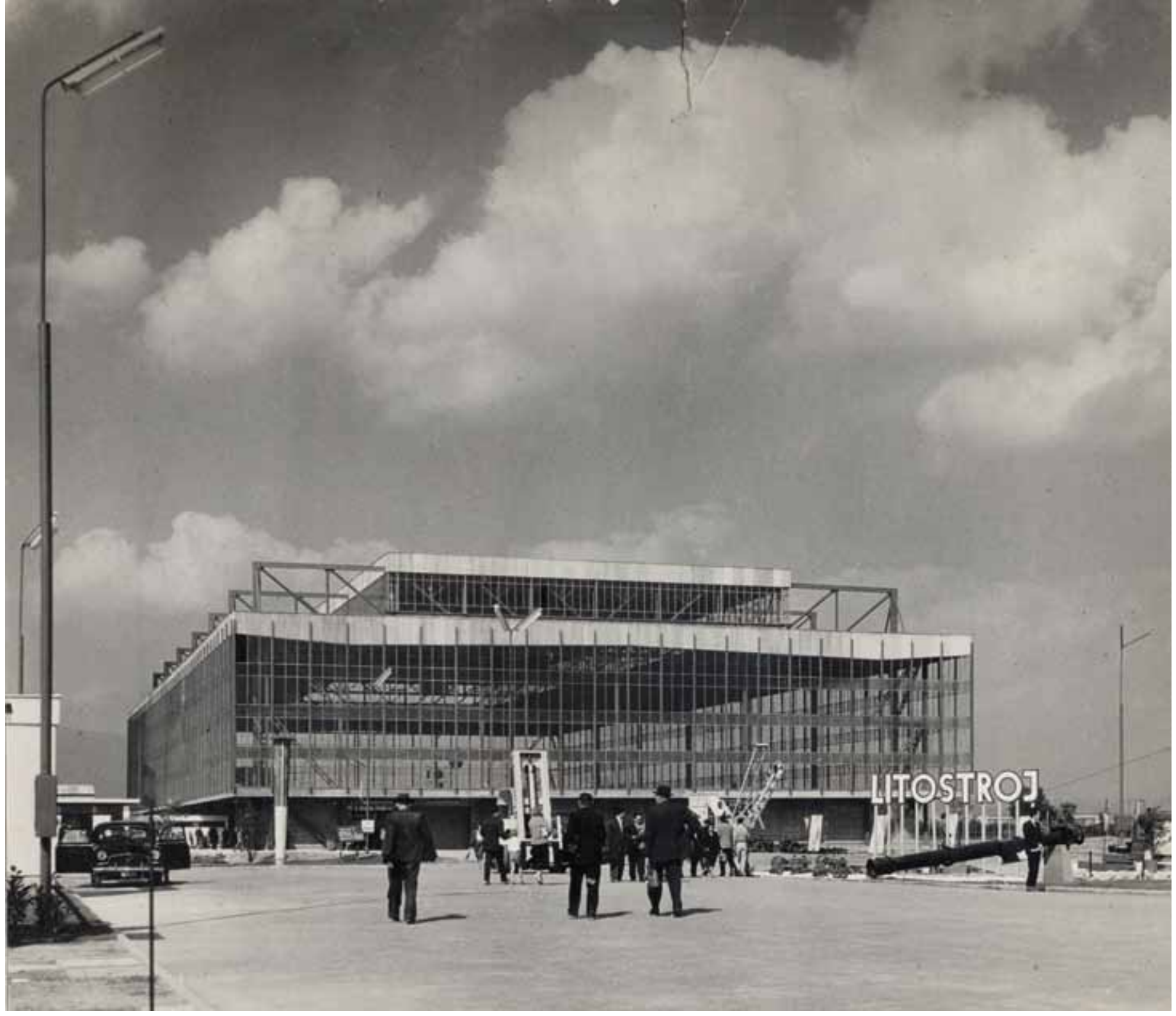

Božidar Rašica, paviljon Mašinogradnje na Zagrebačkom velesajmu, fotografija, fotograf: Ante Roca
Božidar Rašica, Mašinogradnja Pavilion at Zagreb Fair, photograph. Photographer: Ante Roca 
Neven Šegvić, Stambeni blok uz obalu, Zadar, 1955., olovka na papiru, „ARHIV ARHITEKT NEVEN ŠEGVIĆ“, 50,0 x 70,5 cm

Neven Šegvić, Block of flats on the coast, Zadar, 1955, pencil on paper, "ARHIV ARHITEKT NEVEN ŠEGVIĆ", 50.0 x $70.5 \mathrm{~cm}$

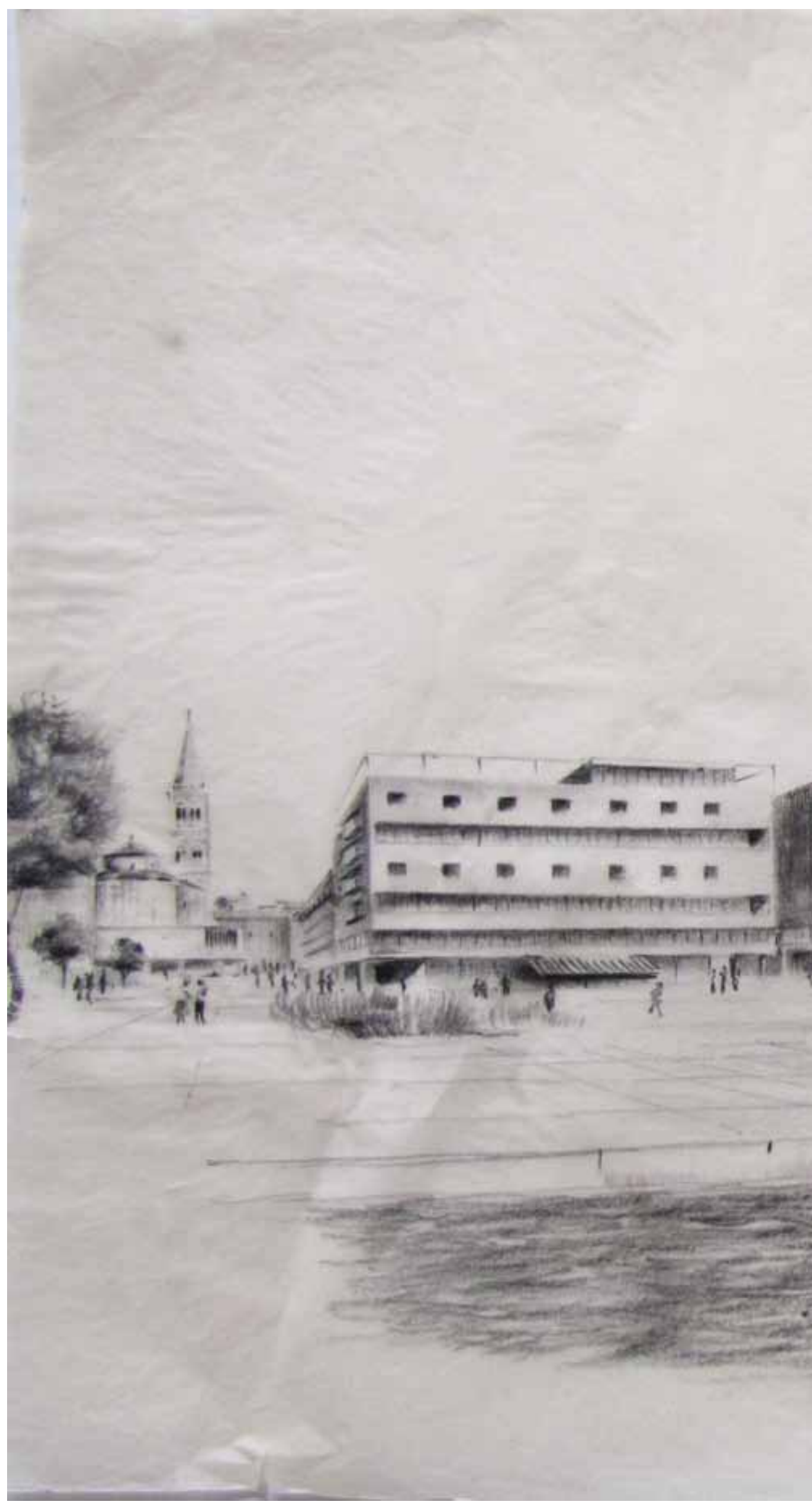




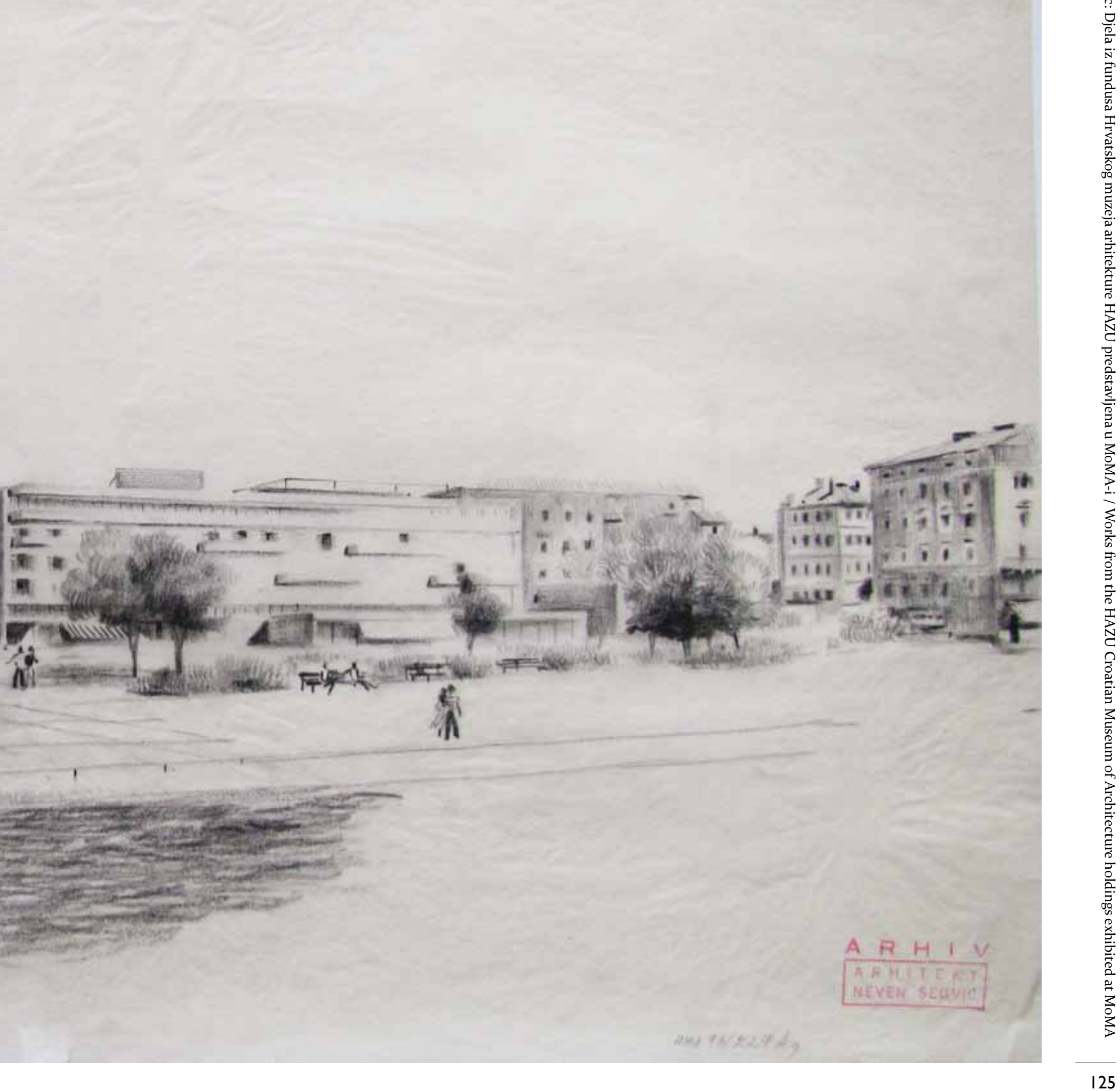


Andrija Čičin-šain i Žarko Vincek, Hotel Libertas, Dubrovnik, 1968-1974., fotografija, fotograf: nepoznat

Andrija Čičin-Šain and Žarko Vincek, Libertas Hotel, Dubrovnik, 1968-1974, photograph. Photographer: unknown

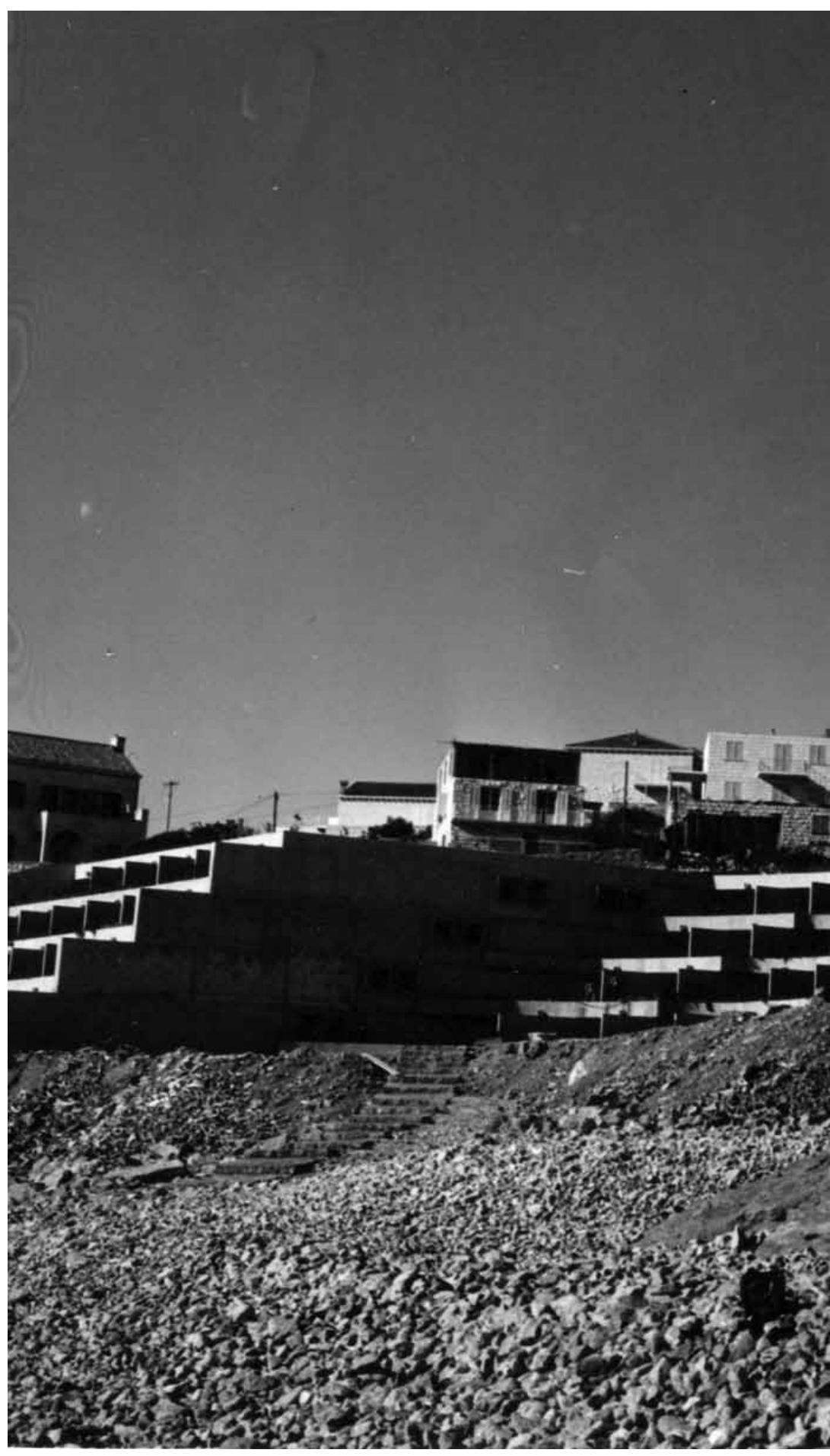




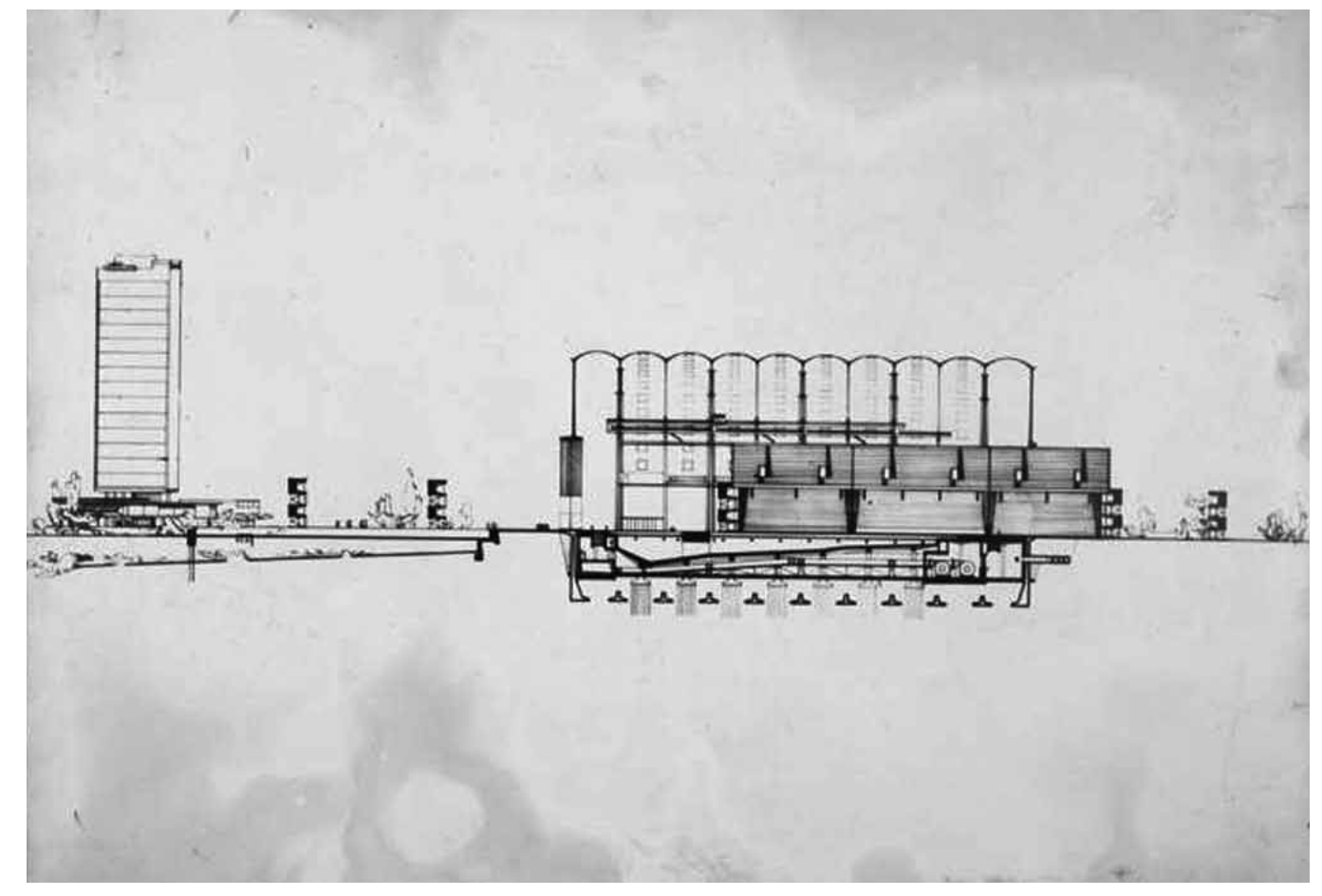

Vladimir Turina, Kombinirano plivalište, Rijeka, 1949., tisak kaširan na drvo, „C, TURINA“ olovkom na poleđini, $48,5 \times 58,5 \times 2,0 \mathrm{~cm}$

Vladimir Turina, Multivalent swimming pool, Rijeka, 1949, print mounted on wood, "C, TURINA" in pen on the back, $48.5 \times 58.5 \times 2.0 \mathrm{~cm}$

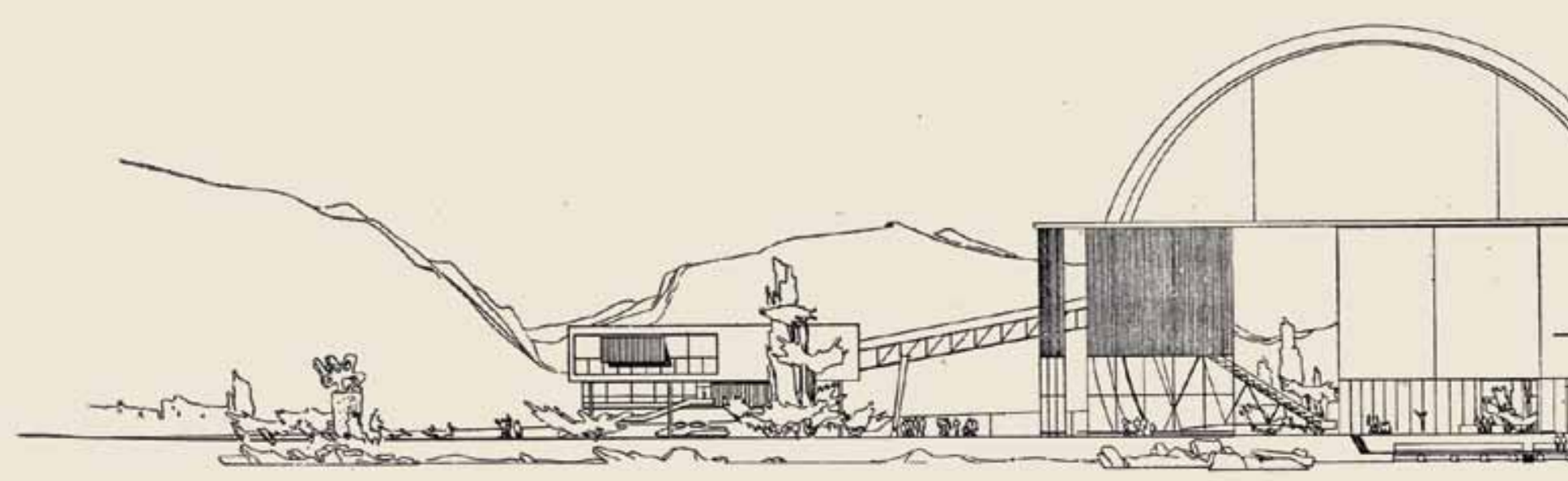


sku stvarnost Sarajeva, i koji je kao i Vjenceslav Richter dobio posebnu sobu u kojoj su prezentirani njihovi radovi. Neidhardt je predstavljen kao arhitekt koji je kombiniranjem lokalne arhitekture sa suvremenim izričajem stvorio novi i drugačiji modernizam prožet povijesnim odrednicama, a Richter kao arhitekt, umjetnik i teoretičar koji $\mathrm{u}$ svom radu koristi interdisciplinarni pristup, $\mathrm{s}$ opsežnom prezentacijom Jugoslavenskog paviljona Expo 58 u Bruxelles-u u Belgiji. Uz njih, svoje sobe dobili su još samo Edvard Ravnikar i Bogdan Bogdanović. Pored originalnih nacrta posjetitelji mogu vidjeti i izuzetno lijepe, novo izrađene ma-
Museum of the People's Revolution in Sarajevo (pic. 28 and 29). A significant place in the exhibition is taken up by Andrija Mutnjaković's National Library in Priština, Kosovo (pic. 31 and 32), an interpretation of regional architecture through modern architectural expression.

Among this series of architects, a significant place is taken by Juraj Neidhardt, a man who designed the architectural reality of Sarajevo, and who, like Vjenceslav Richter, received a separate room in which his works were presented. Neidhardt is presented as an architect who combined local architecture with modern expression to cre-

Vladimir Turina, Kombinirano plivalište,

Rijeka, 1949., tisak kaširan na drvo, „J2“"

olovkom na poleđini, 48,3 x 58,4 X 2,0 cm

Vladimir Turina, Multivalent swimming pool,

Rijeka, 1949, print mounted on wood, "J2" in

pen on the back, $48.3 \times 58.4 \times 2.0 \mathrm{~cm}$

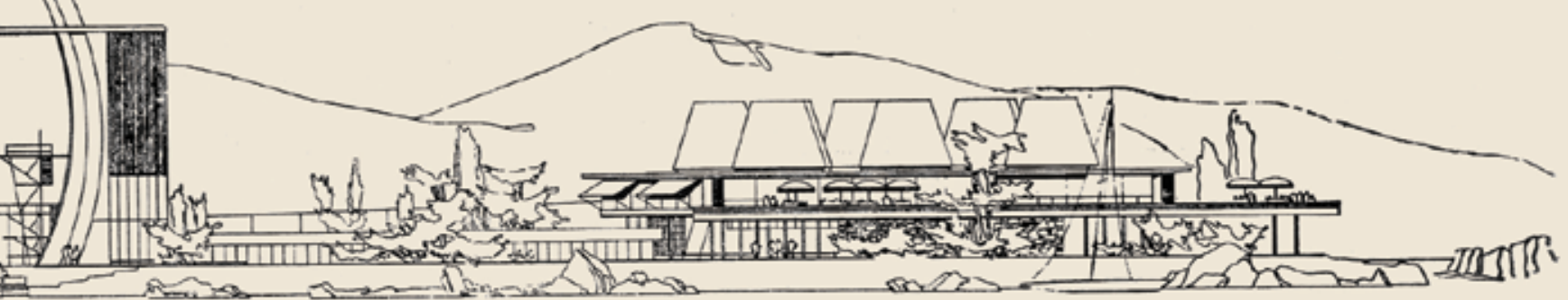



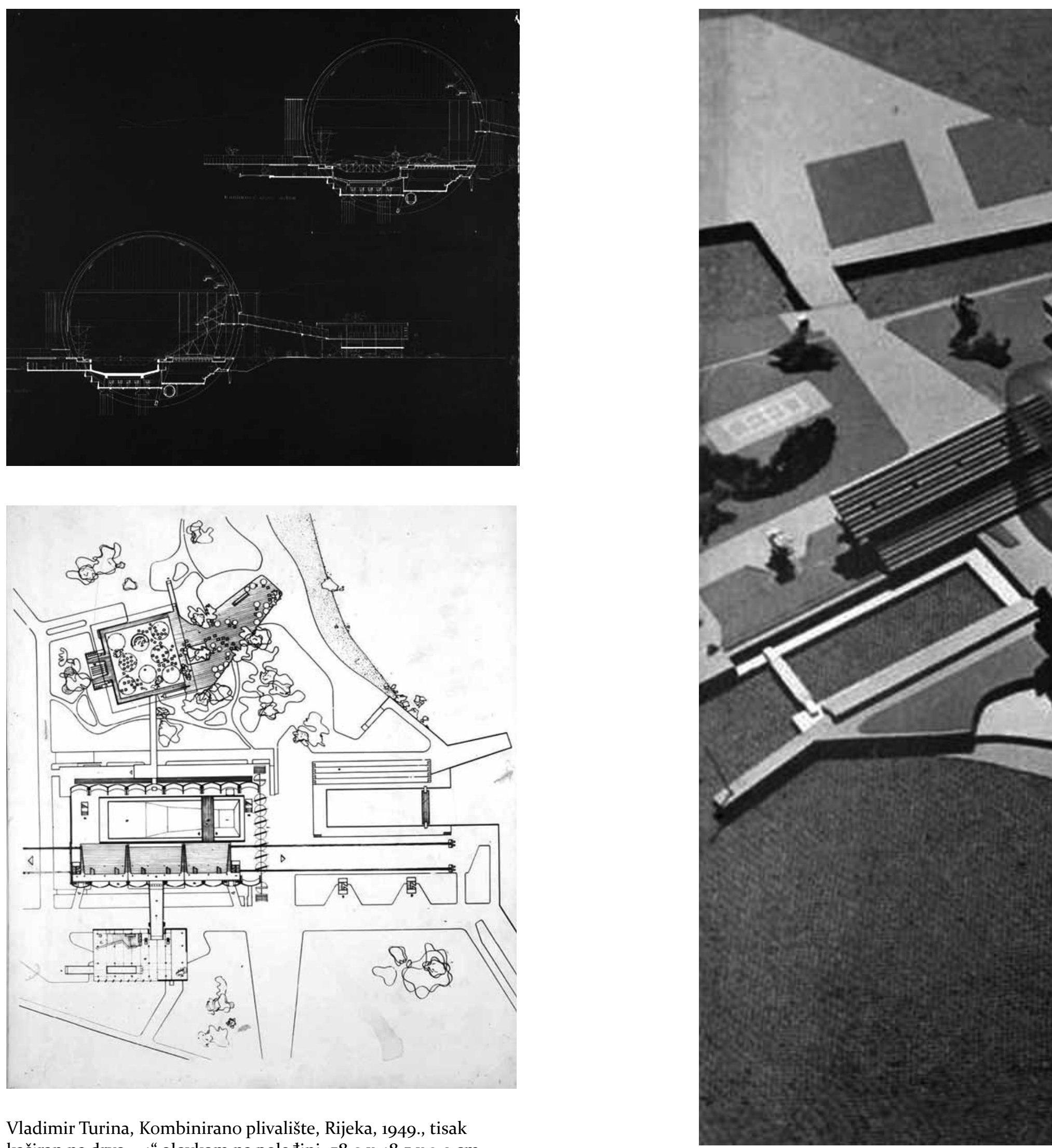

Vladimir Turina, Kombinirano plivalište, Rijeka, 1949., tisak kaširan na drvo, „4“ olovkom na poleđini, 58,o x 48,5 X 2,0 cm

Vladimir Turina, Multivalent swimming pool, Rijeka, 1949, print mounted on wood, " 4 " in pen on the back, $58.0 \times 48.5 \times 2.0 \mathrm{~cm}$ 


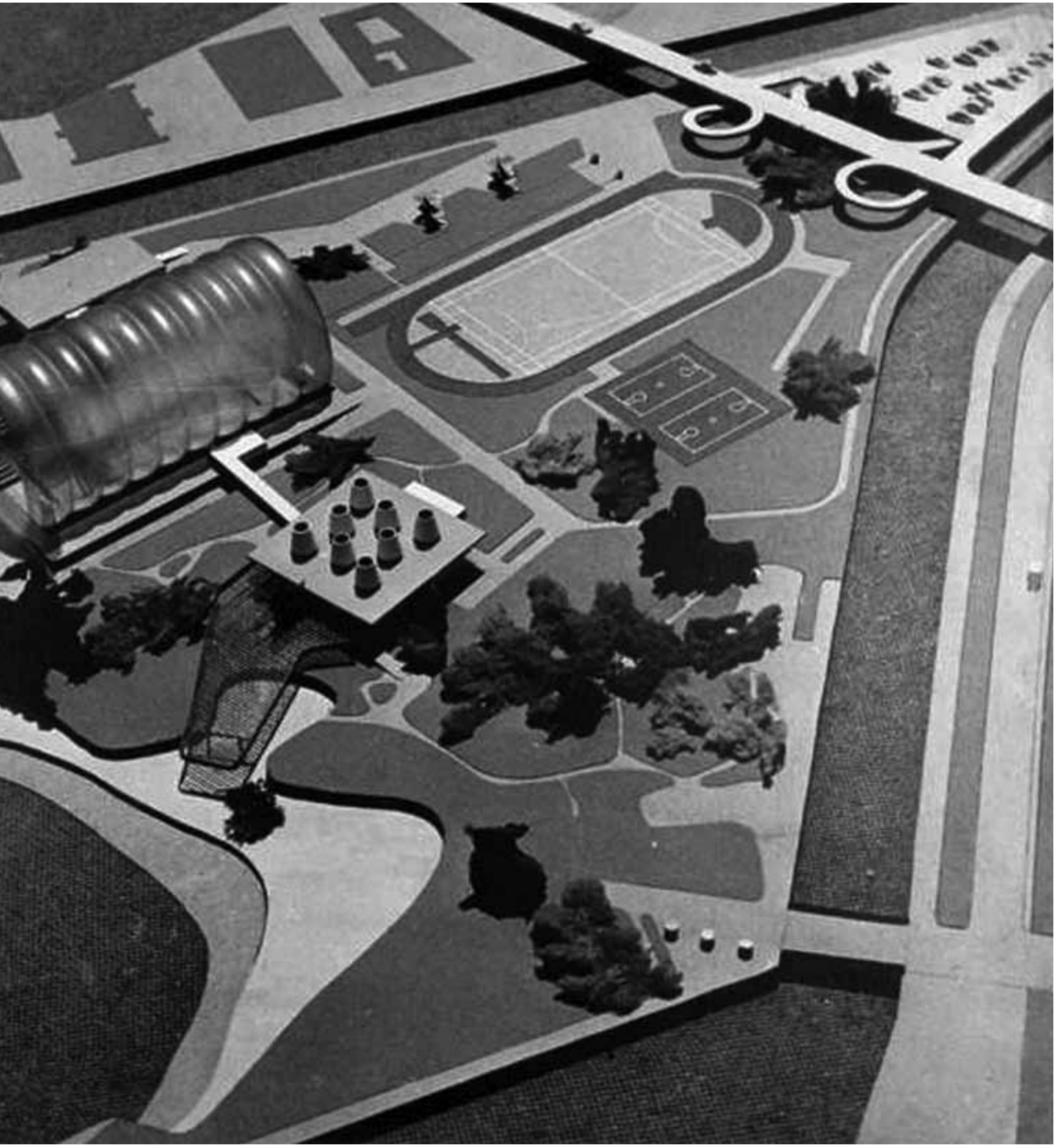

Vladimir Turina, Kombinirano plivalište, Rijeka, 1949., tisak kaširan na drvo, 58,5 X 48,5 X 2,0 cm

Vladimir Turina, Multivalent swimming pool, Rijeka, 1949, print mounted on wood, $58.5 \times 48.5 \times 2.0 \mathrm{~cm}$ 


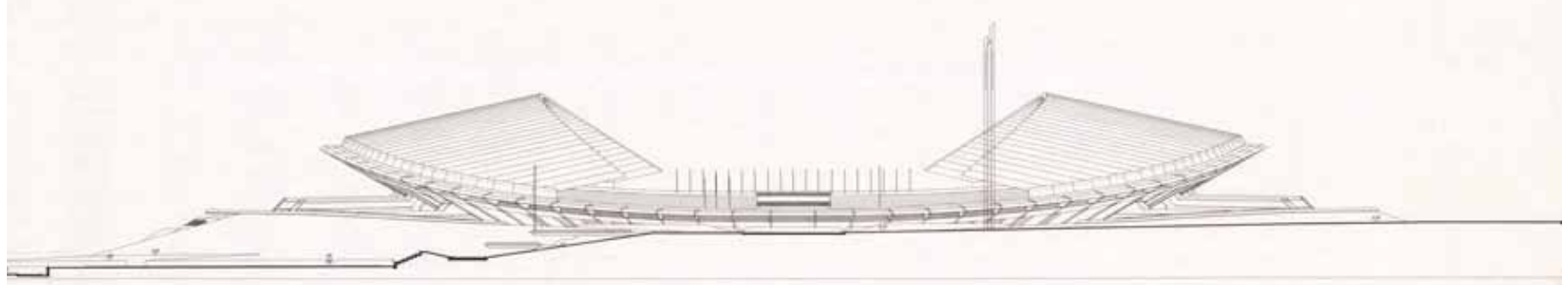

Boris Magaš, Gradski stadion Poljud, Split, 1976-1979., tuš na pausu, prozirna samoljepiva folija, 72,0 x 241,0 cm
Boris Magaš, Poljud City Stadium, Split, 1976-1979, ink on tracing paper, clear self-adhesive foil, 72.0 x 241.ocm

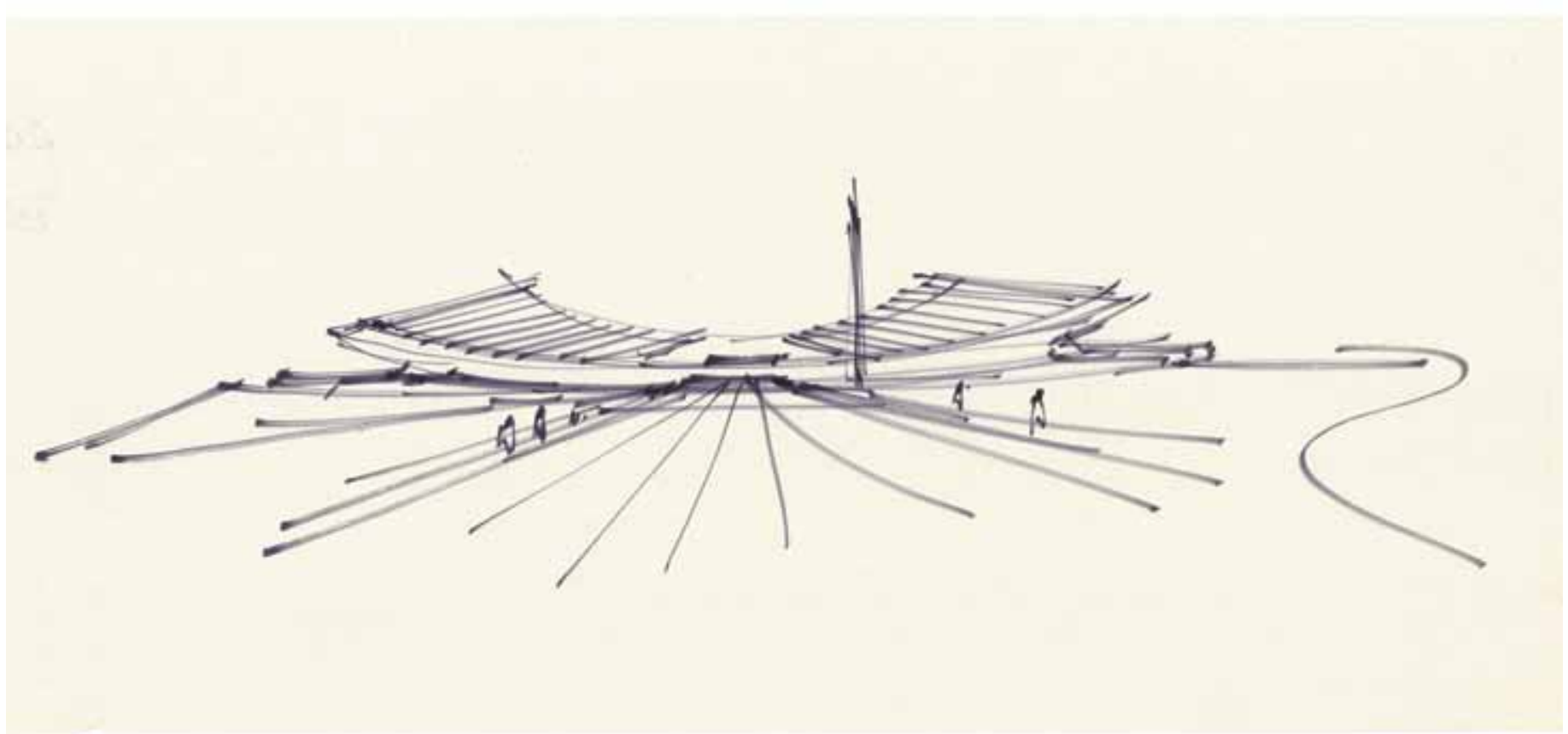

Boris Magaš, Gradski stadion Poljud, Split, 1976-1979., flomaster na papiru za skiciranje, 41,7 X 140,0 cm
Boris Magaš, Poljud City Stadium, Split, 1976-1979, felt pen on sketch paper, 41.7 X $140.0 \mathrm{~cm}$ 


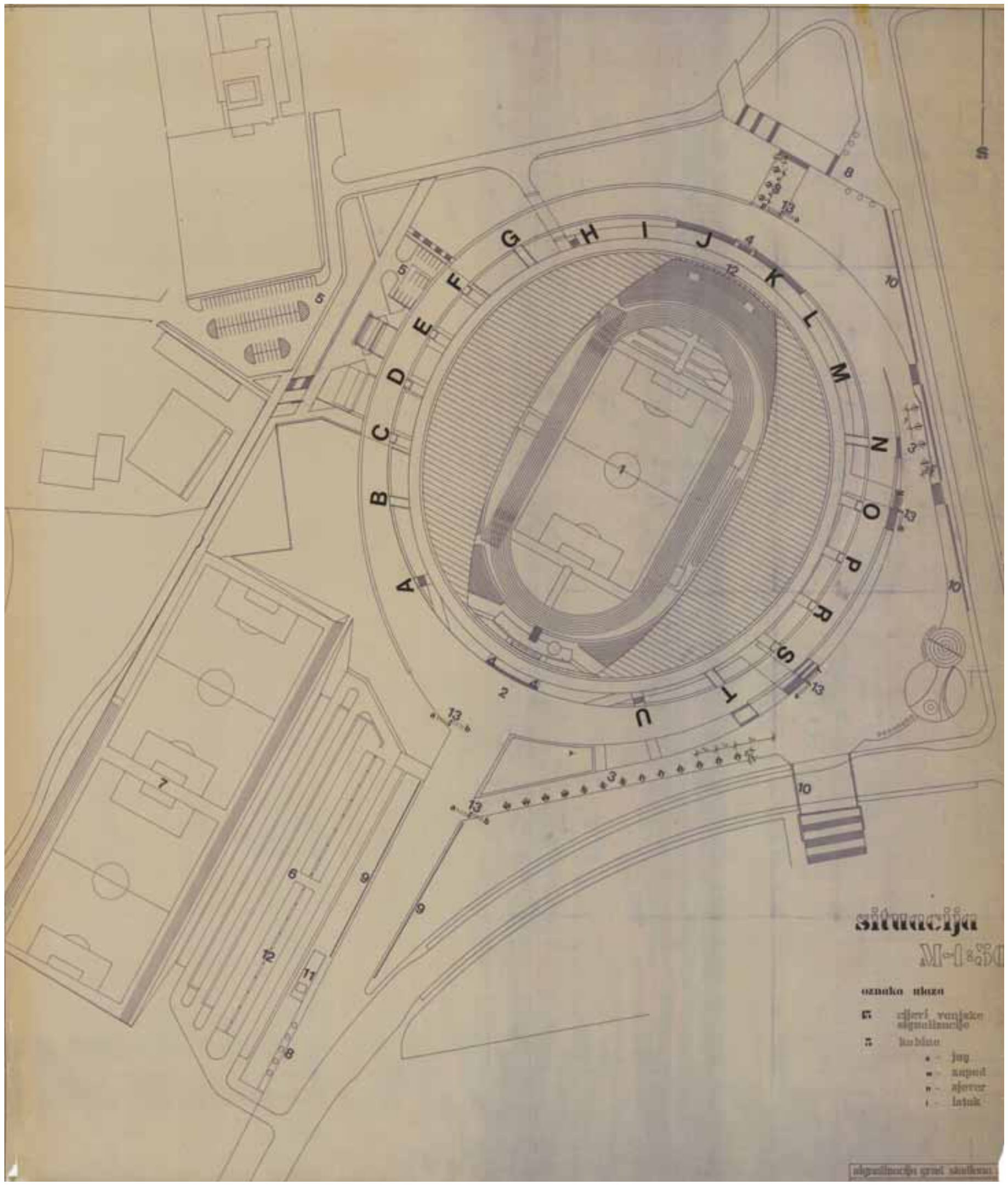

Boris Magaš, Gradski stadion Poljud, Split, 1976-1979., flomaster na papiru za skiciranje, tuš i letraset slova na pausu, 124,0 X 117,0 cm

Boris Magaš, Poljud City Stadium, Split, 1976-1979, felt pen on sketch paper, ink and letraset on tracing paper, $124.0 \times 117.0 \mathrm{~cm}$ 


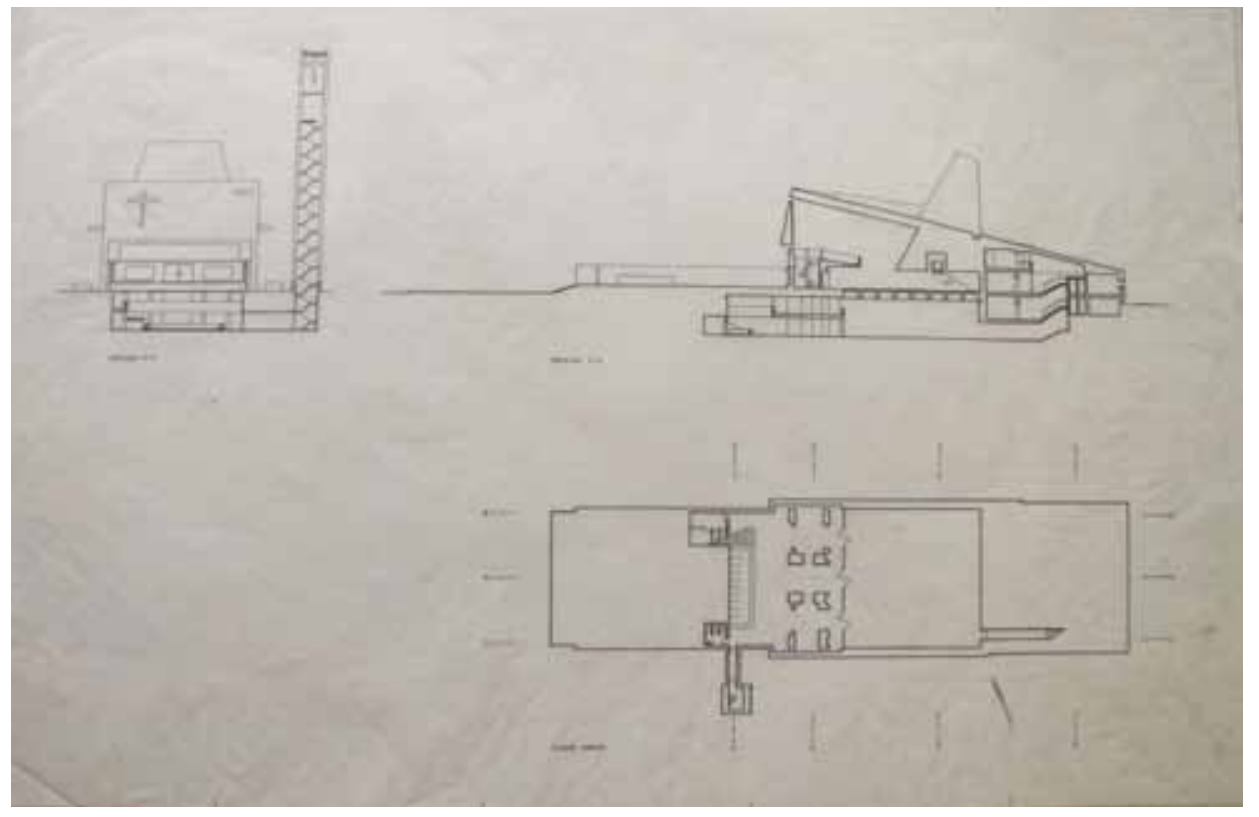

Boris Krstulović i Zvonimir Vrkljan, Katolička katedrala (danas katolička crkva svetog Antuna) u Podgorici, 1963-1969., olovka na pausu, 51,6 x 86, $0 \mathrm{~cm}$

Boris Krstulović and Zvonimir Vrkljan, Catholic cathedral (today Catholic Church of St. Anthony) in Podgorica, 1963-1969, pencil on tracing paper, $51.6 \times 86.0 \mathrm{~cm}$

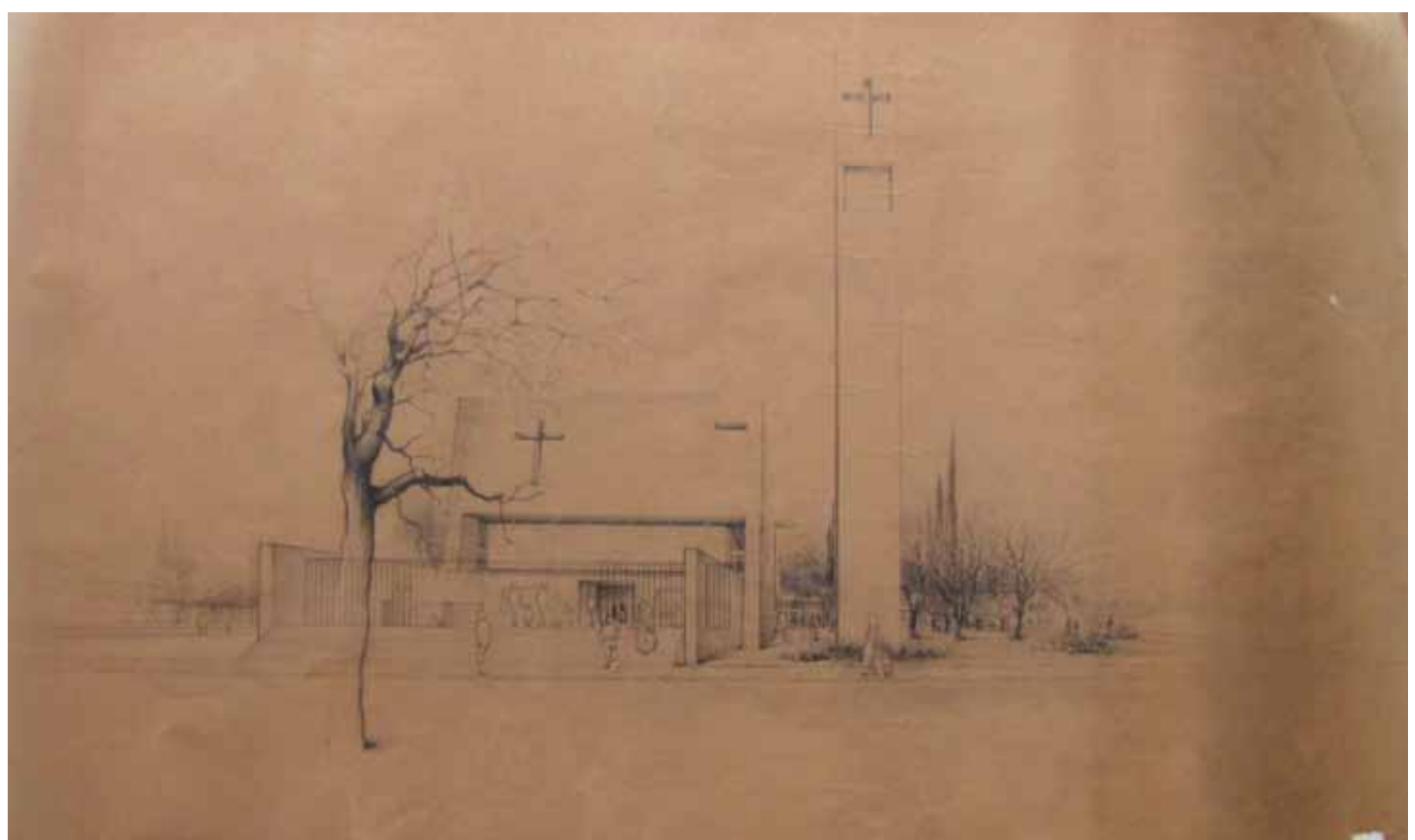

Boris Krstulović i Zvonimir Vrkljan, Katolička katedrala (danas katolička crkva svetog Antuna) u Podgorici, 1963-1969., tuš na pausu, „Presjek F-F“, „Presjek C-C“, „Tlocrt kripte“ ispod pripadajućih crteža“, 62,o x 98,o cm
Boris Krstulović and Zvonimir Vrkljan, Catholic cathedral (today Catholic Church of St. Anthony) in Podgorica, 1963-1969, ink on tracing paper, "Presjek F-F”, "Presjek C-C", “Tlocrt kripte” ispod pripadajućih crteža", 62.0 x $98.0 \mathrm{~cm}$ 
kete Gradskog stadiona Poljud Borisa Magaša, Nacionalne biblioteke u Prištini Andrije Mutnjakovića kao i Šerefudinove Bijele džamije u Visokom Zlatka Ugljena koja ima značajnu arhitektonsku važnost ne samo za taj grad, već i šire.

Posebna pažnja i naglasak stavljen je na planiranje razvoja Jadranske obale iz 1968. godine, budući je baš taj plan, i danas živ, omogućio da obala mora ostane javno dostupna, te ograničio i precizno postavio zone za razvoj turističkih središta, sve kako bi zaštitio prirodni krajobraz i graditeljsko naslijeđe. Turistička arhitektura posebno je upečatljivo obrađena, a u arhitektonskom izrazu prisutne su činjenice i detalji iz ne tako daleke prošlosti koji su bili vrijednost koju smo u brzini življenja načas zaboravili ili je nismo vidjeli. Analizirajući poruku toga vremena, iščitava se vrijednost koja je nesporno bila na europskom vrhu, a danas je većina znatnog arhitektonskog fonda izgrađenog u turističke svrhe na ovaj ili onaj način devastirana. U želji za odbacivanjem atributa i naslijeđa socijalizma, odbacili smo i devastirali velik dio kulturne baštine iz doba velikih turističkih investicija i snažnih arhitektonskih ambicija. Tu je i natječajni projekt regulacije Zadra Ivana Vitića (sl.3o), kao i projekt Split 3 čiji plan potpisuju Braco Mušič, Marijan Bežan i Nives Starc. Stanovanje oko pješačkih ulica okruženih zgradama splitskih arhitekata Dinka Kovačića, Ive Radića, Frane Gotovca, kao i drugih talentiranih arhitekata ${ }^{9}$ koje prizivaju mediteranski ugođaj, kontrapunkt je projektima koji su stvarali Nove gradove, kao što je bio slučaj u Zagrebu i Beogradu, s puno zelenila i otvorenog prostora između zgrada.

Ova izložba otvara mogućnost da još jednom, s odmakom, promotrimo nastalu arhitekturu i odnose koje je stvarala, jer ponekad treba dati vremena i kući i mjestu da budu prepoznati. Suočavanje sa svim dobrim i lošim u suvremenoj arhitekturi i aktualnim stanjem u prostoru može biti dobar početak, a sustavna analiza donijeti će i stav kakvu arhitekturu i kakav prostor želimo. „Arhi-

9 Skansi, L., 2018: 157 ate a new, different form of modernism imbued with historical determinants, while Richter is portrayed as an architect, artist, and theoretician whose work uses an interdisciplinary approach through an extensive presentation of his Yugoslav Pavilion at Expo 58 in Brussels. Aside from these two, only Edvard Ravnikar and Bogdan Bogdanović received their own rooms. In addition to original designs, visitors can also see beautiful new models of Boris Magašs Poljud City Stadium, Andrija Mutnjakovićs National Library of Pristina, and Zlatko Ugljen's Šerefudin White Mosque in Visoko, which has great architectural significance not only to the city, but to the region as well.

Special attention and focus is placed on the planned development of the Adriatic Coast in 1968; this plan, which is still in motion today, allowed the coastline to remain publicly accessible and limited the development of tourist areas to precisely defined zones in order to protect the natural landscape and architectural heritage. Tourist architecture is especially well elaborated; its architectural expression displays facts and details from the not-so-distant past representing local values that, due to the hurried modern lifestyle, are either temporarily forgotten or go unnoticed. An analysis of the message of the time shows value that was indisputably among the highest in Europe, however, the majority of significant architecture built for tourism has today been devastated in one way or another. Out of the desire to discard the attributes and heritage of socialism, we have discarded and destroyed a great deal of cultural heritage from a time of great investment in tourism and powerful architectural ambitions. This includes Ivan Vitić's tender project for the urban plan of the city of Zadar (pic. 30), as well as the Split 3 residential project by Braco Mušič, Marijan Bežan, and Nives Starc. Residential architecture around pedestrian streets surrounded by buildings by Split architects Dinko Kovačić, Ivo Radić, Frano Gotovac, and other talented architects ${ }^{9}$

9 Skansi, L., 2018: 157 

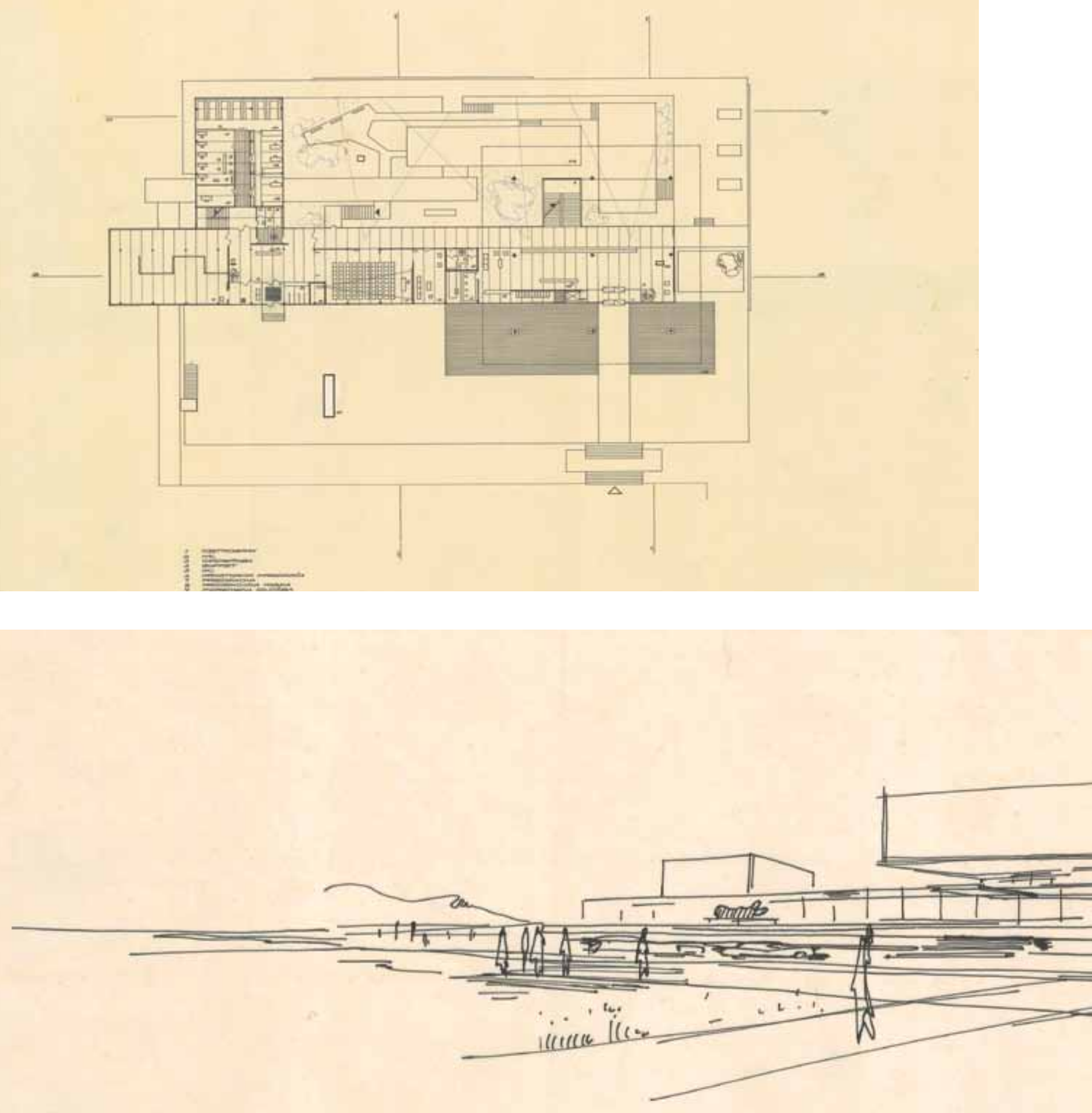

Boris Magaš, Muzej narodne revolucije, Sarajevo (danas Povijesni muzej Bosne i Hercegovine), 1958-1962., tuš na pausu, „Građevinskoprojektni biro za metalne (...) 20.XI.1958., 53,5 x 57,0 cm 
Boris Magaš, Muzej narodne revolucije, Sarajevo (danas Povijesni muzej Bosne i Hercegovine), 1958-1962., tuš i olovka na pausu, „Građevinsko-projektni biro za metalne (...) 20.XI.1958., 54,5 x 86,0 cm

Boris Magaš, Museum of the People's Revolution, Sarajevo (today Bosnia and Herzegovina Historical Museum), 19581962, ink and pencil on tracing paper, "Građevinsko-projektni biro za metalne (...) 20.XI.1958.", 54.5 x 86.0cm and Herzegovina Historical Museum), 1958-1962, ink on tracing paper, “Građevinsko-projektni biro za metalne (...) 20.XI.1958., 53.5 x $57.0 \mathrm{~cm}$ 


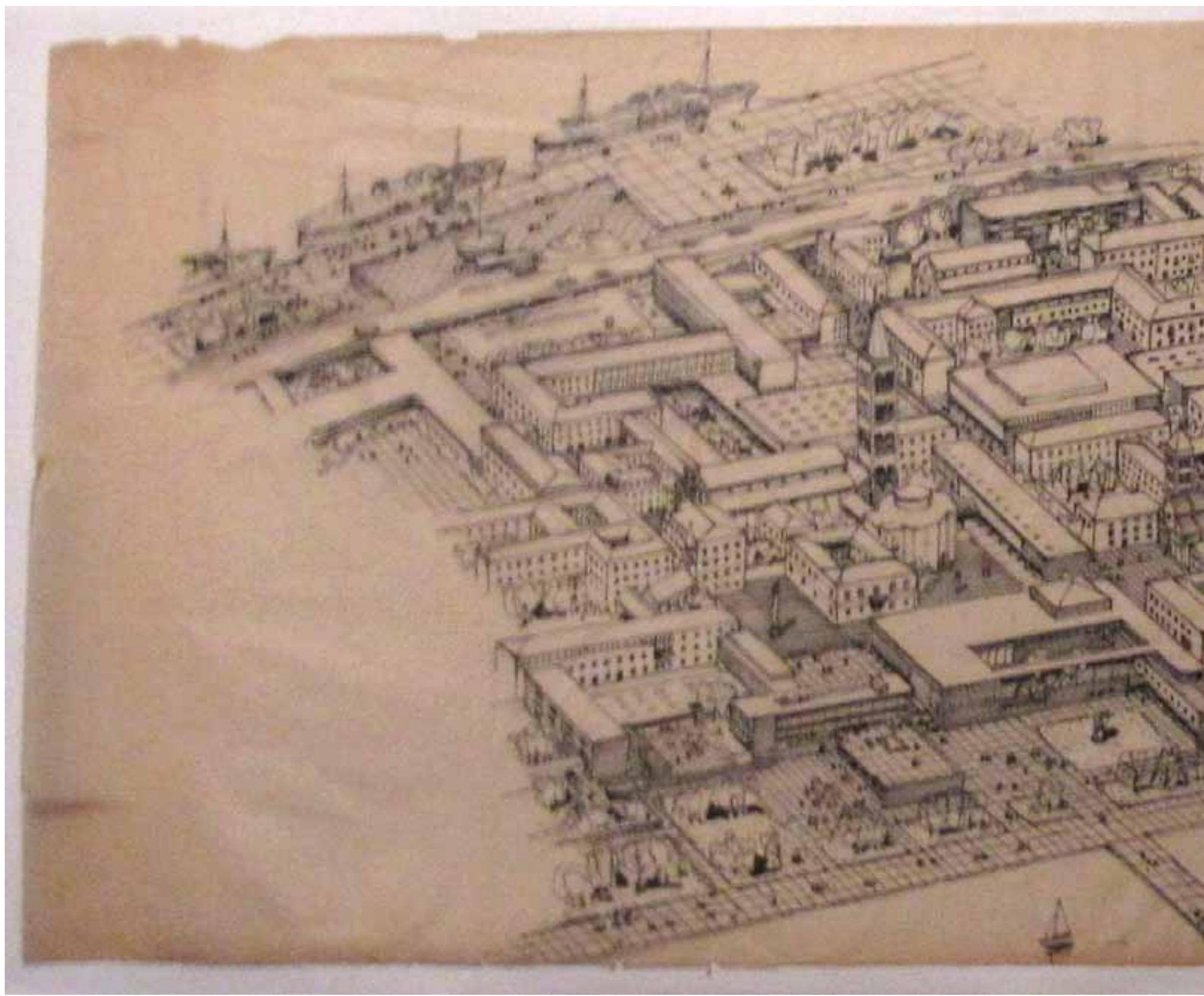

Ivan Vitić, regulacija Zadra, natječajni projekt, tuš na pausu (podloga: karton), „Aksonometrijski pogled centralnog dijela grada. Mjerilo 1:500", 6o,o x 148,5 cm 
Ivan Vitić, Urban design of Zadar , tender project, ink on tracing paper (mounted on cardboard), "Aksonometrijski pogled centralnog dijela grada. Mjerilo 1:50o", 60.0 x $148.5 \mathrm{~cm}$ 
tektura je zarobljena u procesima i paradoksima društva, ali sposobna transformirati ih u svoj vlastiti izraz: djeluje po paralelnim, ali ipak drugačijim pravilima. ${ }^{\text {"1o }}$ rečenica je povjesničara arhitekture W.J.R. Curtis-a koja u cijelosti može opisati poruku izložbe.

10 Curtis, W.J.R., 2000: 13 who invoke a Mediterranean atmosphere serve as a counterpoint to projects that created new cities with much greenery and open space between buildings, as was the case in Zagreb and Belgrade.

This exhibition makes it possible to re-examine the architecture created during this period and the relationships it created from a distance, because both buildings and cities sometimes need time to be recognised. Coming to terms with all of the good and the bad in modern architecture and the current state on the ground may be a good start, but systematic analysis will also provide an opinion as to the kind of architecture and space we want. The following words by William J.R. Curtis describe the entire message of the exhibition: "Architecture is rooted in the processes and paradoxes of society, but it also transforms these into its own terminology: it works by parallel but different rules." ${ }^{10}$

10 Curtis, William J.R., 200o: 13 


\section{TOWARD A CONCRETE UTOPIA: ARCHITECTURE IN YUGOSLAVIA 1948-1980}

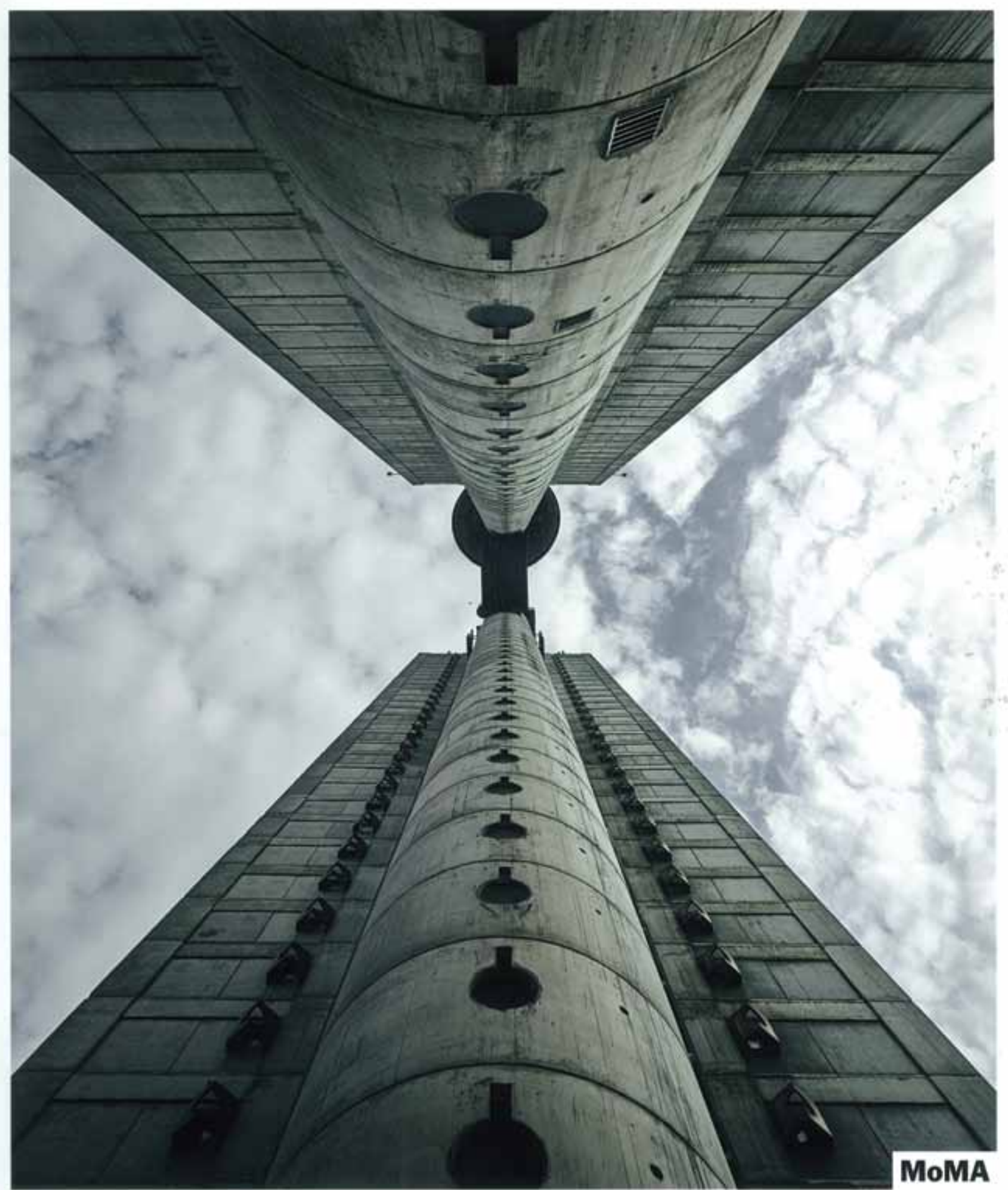

Naslovnica, Katalog izložbe, (2018.), Toward a Concrete Utopia: Architecture in Yugoslavia, 1948 - 1980, The Museum of Modern Art, New York
Title page, exhibition catalogue, (2018), Toward a Concrete Utopia: Architecture in Yugoslavia, 1948 1980, Museum of Modern Art, New York 

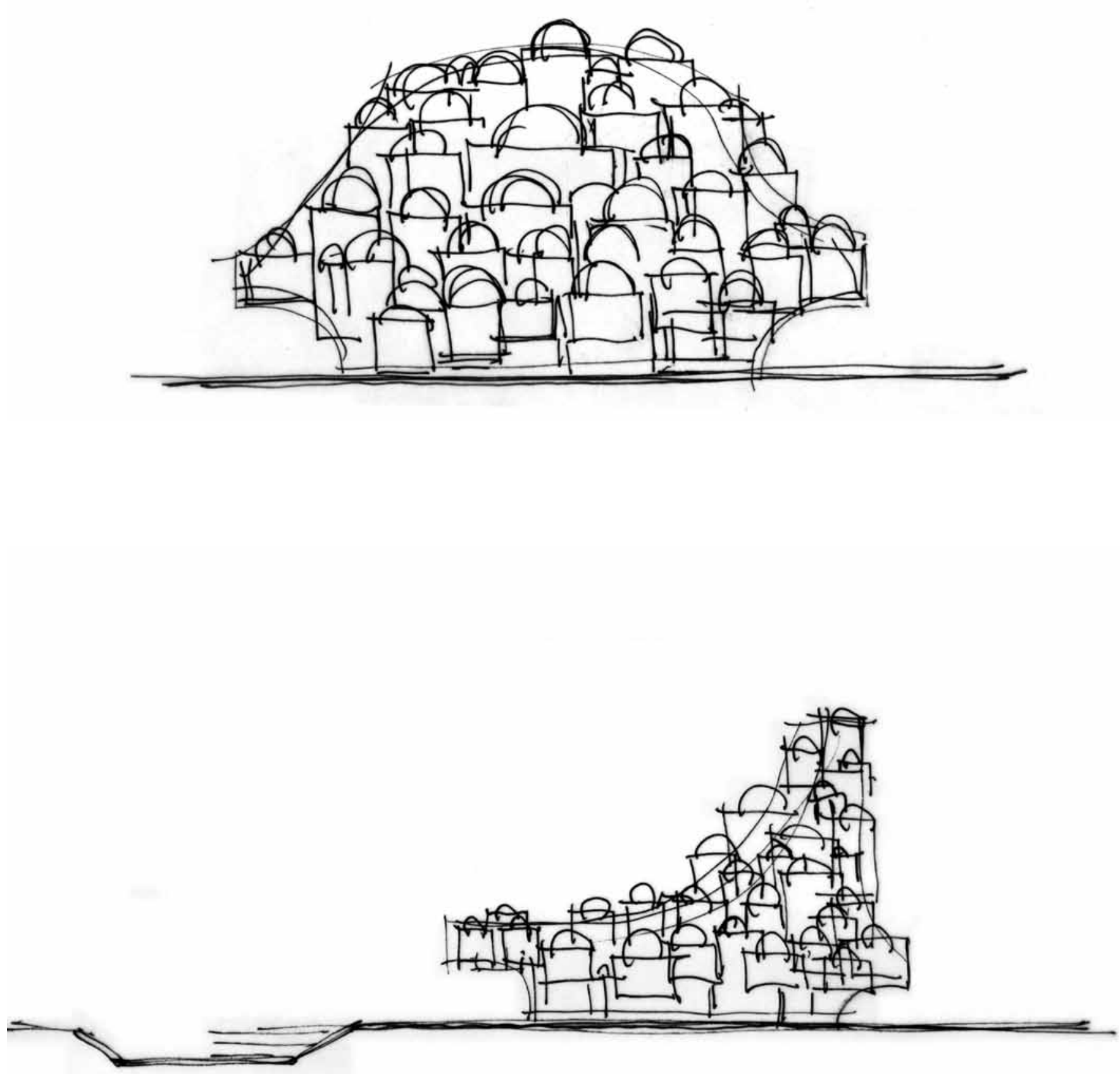

Andrija Mutnjaković, Nacionalna biblioteka (danas Nacionalna i sveučilišna biblioteka Kosova), Priština, Kosovo, 1982., 65,o x 97,o cm, tuš, letraset i letraton na pausu, privatni arhiv Andrija Mutnjaković
Andrija Mutnjaković, National Library (today Kosovo National and University Library), Priština, Kosovo, 1982, $65.0 \times 97.0 \mathrm{~cm}$, ink, letraset and letraton on tracing paper, private archive of Andrija Mutnjaković 


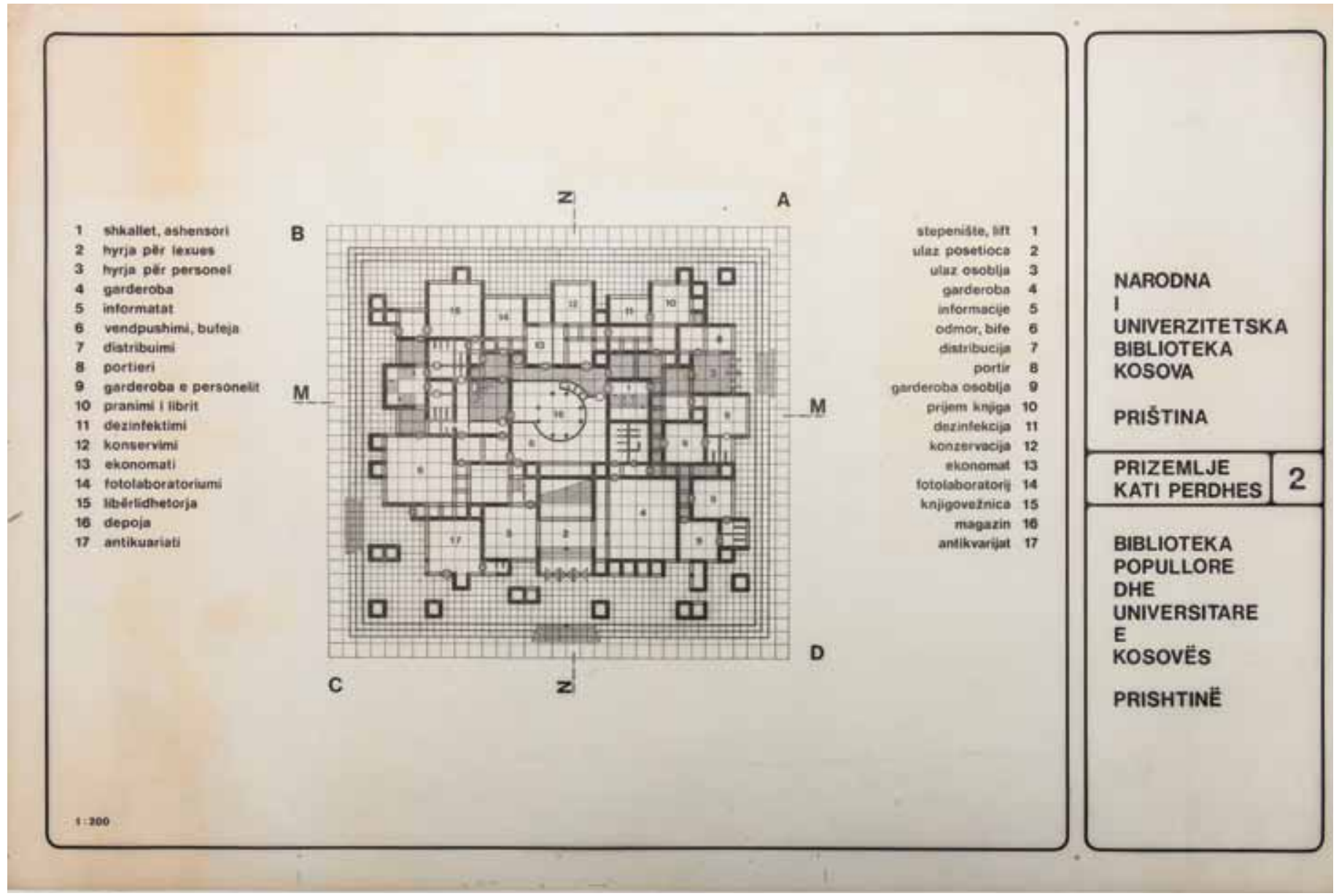

Andrija Mutnjaković, Nacionalna biblioteka (danas Nacionalna i sveučilišna biblioteka Kosova), Priština, Kosovo, 1982., flomaster na papiru, 21,0 x 30,0 cm, privatni arhiv Andrija Mutnjaković
Andrija Mutnjaković, National Library (today Kosovo National and University Library), Priština, Kosovo, 1982, felt pen and pencil, $21.0 \times 30.0 " \mathrm{~cm}$, private archive of Andrija Mutnjaković 
Literatura:

1. Curtis, W.J.R., (200o.), Modern arhitecture since 1900, III edition, Phaidon Press Limited, London

2. Katalog izložbe, (2018.), Introduction, Toward a Concrete Utopia: Architecture in Yugoslavia, 1948 - 1980, The Museum of Modern Art, New York
Bibliography:

1. Curtis, William J.R., (200o.), Modern arhitecture since 1900, III edition, Phaidon Press Limited, London

2. Exhibition catalogue, (2018), Introduction, Toward a Concrete Utopia: Architecture in Yugoslavia, 1948 - 1980, The Museum of Modern Art, New York

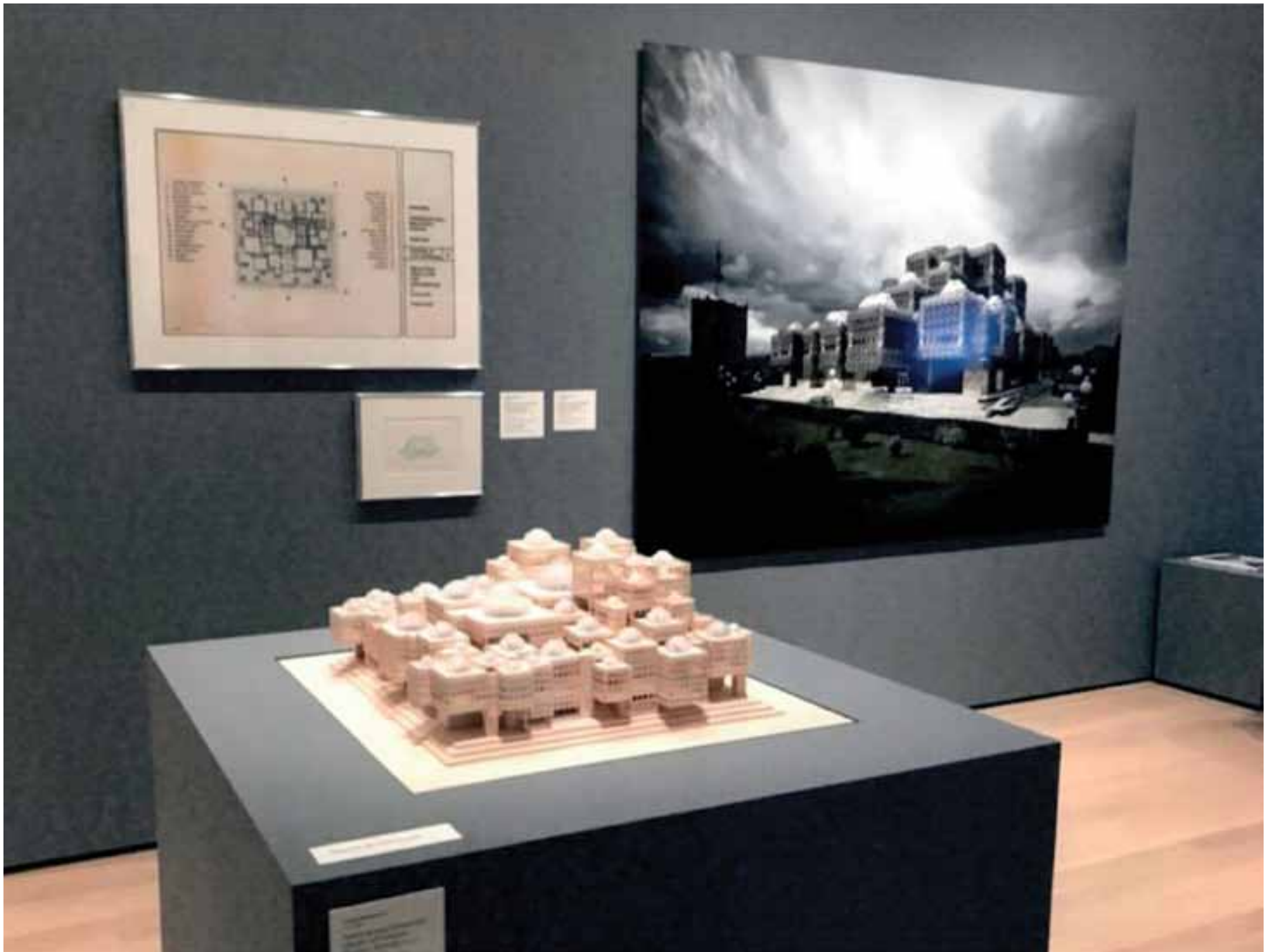

Maketa Nacionalne biblioteke u Prištini Andrije Mutnjakovića, izrada - studenti arhitekture s fakulteta Cooper Union, New York
Model of Andrija Mutnjaković's National Library in Priština, design - architecture students from the Cooper Union, New York, and Florida Atlantic University 
3. Magaš, B., (2014.), Misli o arhitekturi, [priređivač i urednik Alen Žunić], Hrvatska akademija znanosti i umjetnosti - Hrvatski muzej arhitekture; Sveučilište u Zagrebu - Arhitektonski fakultet, UPI-2M PLUS, Zagreb

4. Mohorovičić, A., (1975.), Prilog analizi nekih osnovnih problema teorije arhitekture - O kategorijama apsolutnog i relativnog u teoriji arhitekture, Acta architectonica I, Arhitektonski fakultet Sveučilišta u Zagrebu, Zagreb
3. Magaš, B., (2014), Misli o arhitekturi, [ed. Alen Žunić], Croatian Academy of Sciences and Arts - Croatian Museum of Architecture; University of Zagreb - Faculty of Architecture, UPI-2M PLUS, Zagreb

4. Mohorovičić, A., (1975), Prilog analizi nekih osnovnih problema teorije arhitekture - O kategorijama apsolutnog i relativnog u teoriji arhitekture, Acta architectonica I, Faculty of Architecture, University of Zagreb, Zagreb

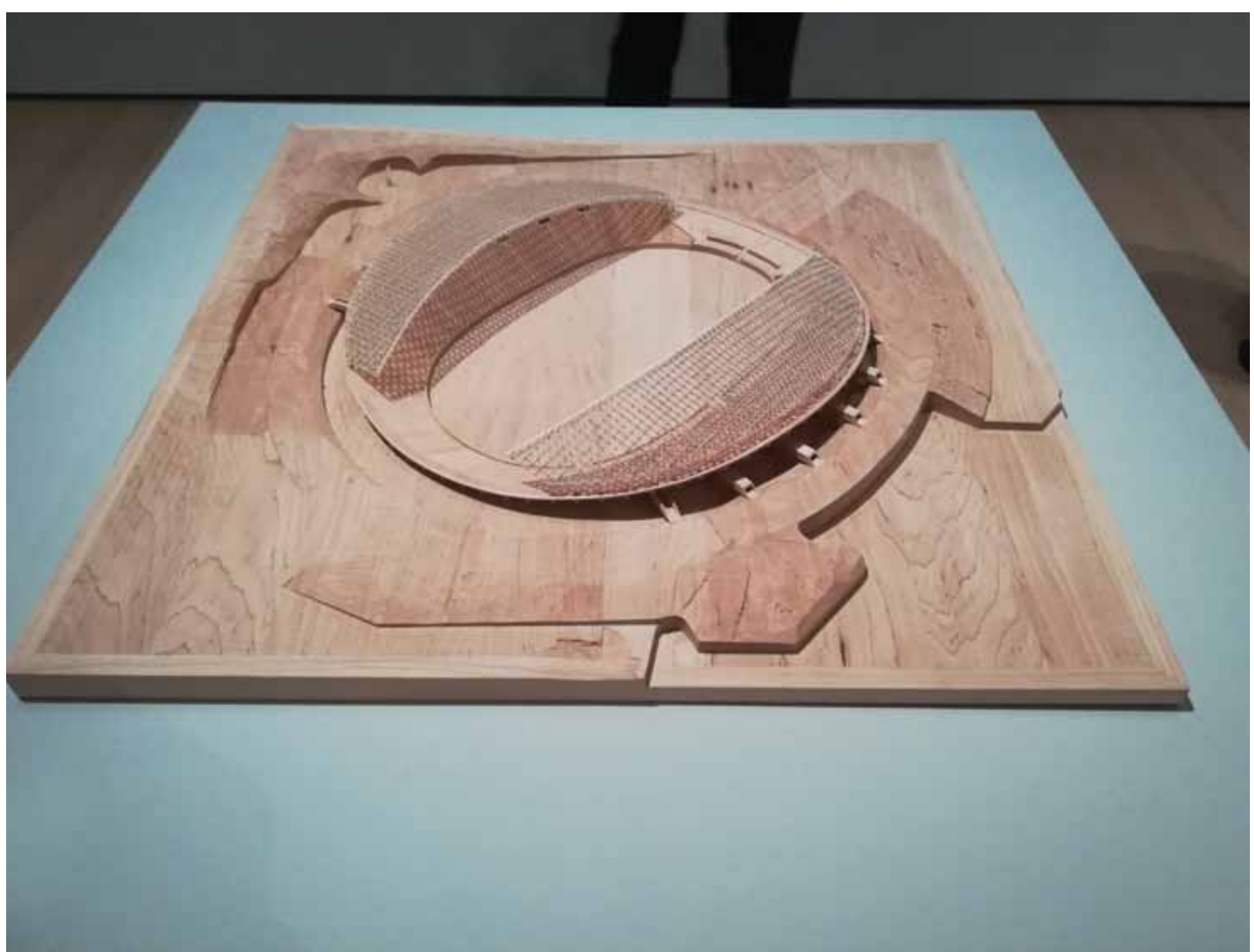

Maketa Gradskog stadiona Poljud u Splitu Borisa Magaša, izrada - studenti arhitekture s fakulteta Cooper Union, New York
Model of Boris Magašs Poljud City Stadium in Split, design - architecture students from the Cooper Union, New York, and Florida Atlantic University 
5. Skansi, L., (2018.), Split 3, Toward a Concrete Utopia: Architecture in Yugoslavia, 1948 -1980, The Museum of Modern Art, New York

6. Stierli, M., Kulić, V., (2018.), Introduction, Toward a Concrete Utopia: Architecture in Yugoslavia, 1948 - 1980, The Museum of Modern Art, New York

7. Tonković, Z., (2005.), Radovan Nikšić - vitalnost moderniteta, Radovan Nikšić 1920.-1987., Arhiv arhitekata, Izložba iz zbirke Hrvatskog muzeja arhitekture HAZU, Zagreb
5. Skansi, L., (2018), Split 3, Toward a Concrete Utopia: Architecture in Yugoslavia, 1948 -198o, The Museum of Modern Art, New York

6. Stierli, M., Kulić, V., (2018), Introduction, Toward a Concrete Utopia: Architecture in Yugoslavia, 1948 - 1980, The Museum of Modern Art, New York

7. Tonković, Z., (2005), Radovan Nikšić - vitalnost moderniteta, Radovan Nikšić 1920.-1987., Architect's archive, Exhibition from the collection of the HAZU Croatian Museum of Architecture, Zagreb 